Marli Aparecida Silva Athaniel

SIGNIFICADOS E IMPLICAÇÕES DE SER MÃE NO PROCESSO

SAÚDE-DOENÇA DE MULHERES COM AIDS

São Paulo

2006 
Marli Aparecida Silva Athaniel

\title{
SIGNIFICADOS E IMPLICAÇÕES DE SER MÃE NO PROCESSO SAÚDE-DOENÇA DE MULHERES COM AIDS
}

\author{
Dissertação de Mestrado apresentada à \\ Escola de Enfermagem da Universidade de \\ São Paulo - Área de Concentração: \\ Enfermagem em Saúde Coletiva
}

Orientadora: Prof ${ }^{\mathrm{a}}$ Dr $^{\mathrm{a}}$ Renata Ferreira Takahashi

São Paulo

2006 
Catalogação na publicação (CIP)

Biblioteca "Wanda de Aguiar Horta" da EEUSP

Athaniel, Marli Aparecida Silva.

Significados e Implicações de ser mãe no processo saúde-doença de mulheres com aids. / Marli Aparecida Silva Athaniel. - São Paulo: M. A. S. Athaniel, 2006.

$127 \mathrm{p}$.

Dissertação (Mestrado) - Escola de Enfermagem da Universidade de São Paulo.

Orientadora: Profa. Dra ${ }^{\mathrm{a}}$. Renata Ferreira Takahashi.

1. Síndrome de Imunodeficiência Adquirida 2. Mães (Transmissão)

3. Doenças Transmissíveis (HIV) I. Título. 


\section{Dedicatória}

"As sociedades devem ser julgadas por sua capacidade de fazerem felizes os indivíduos que as compõem"

(Alex de Tocquenville)

Dedico esta dissertação às mulheres usuárias do SAE DST/AIDS Cidade Líder que, gentilmente, se disponibilizaram às minhas indagações. São mães guerreiras que mostraram uma força excepcional em lidar com os revezes da vida e apostaram no sucesso da maternidade, revivificando o pensamento de Fernando Pessoa: "Tudo vale a pena, se a alma não é pequena." 


\section{Agradecimentos}

A Deus, fonte maior!

Aos meus pais, Luiza de Moura Silva e João Catingueiro Silva, exemplos perfeitos de retidão de caráter e disposição para o trabalho. A minha mãe, pelos mimos maternos para com esta pesquisadora, mulher adulta, que por vezes se vê criança à sombra protetora do seu afeto maternal.

Ao meu esposo, Joel Jayme Athaniel Silva, pela parceria positiva e apoio incondicional.

A minha filha Mariana, principal motivação, pela afetividade, apoio, toques...

Às equipes de trabalho do SAE - DST/AIDS Cidade Líder e da UBS Jardim Nove de Julho, pela paciência, compreensão e colaboração durante o meu processo de pesquisa.

Agradeço especialmente à Prof. ${ }^{a}$ Doutora Renata Ferreira Takahashi, minha orientadora que, em um verdadeiro processo de maiêutica, soube serenamente conduzir meu raciocínio, extraindo o melhor de mim, para que nascesse este trabalho.

A todas as docentes das disciplinas ministradas na Pós-Graduação da Escola de Enfermagem da USP, nos anos de 2004 e 2005, que ajudaram a acimentar o meu caminho rumo ao conhecimento.

Aos funcionários da Escola de Enfermagem da USP pelo apoio logístico.

A Profa Antonia Cileide pela dedicação e apoio 
Tocar-te ...tocar seu corpo de criança, tão hábil em arrepios, teu corpo de mãe, casa profunda onde cada um se sente em casa, teu corpo de mãe que foi repleto de canções e que ainda hoje sofre e com tanta ausência se espanta.

(Jean Yves Leloup) 


\section{Resumo}

As mulheres infectadas por aids, ao engravidarem, enfrentam múltiplas dificuldades, entre elas o receio da transmissão vertical. Objetivou-se com este estudo identificar as características sócio-demográficas e as condições de vida e trabalho de mulheres com aids; identificar os significados atribuídos por elas à maternidade e conhecer as implicações de ser mãe no processo saúdedoença. Trata-se de um estudo exploratório, qualitativo, com 16 mulheres com AIDS, matriculadas num serviço especializado em DST/AIDS do município de São Paulo. Os dados foram obtidos meio de consulta aos prontuários clínicos e de entrevista com roteiro semi-estruturado e submetidos posteriormente à análise de conteúdo, sendo interpretados à luz do conceito de Vulnerabilidade. As características do grupo de mulheres estudadas são: solteiras, idade reprodutiva, baixa escolaridade e condições de vida precárias, infectadas por via sexual, souberam do diagnóstico tardiamente. Dos significados da maternidade, emergiram três categorias: a primeira "a vivência da gravidez" abrangendo os determinantes, os sentimentos e as repercussões da gravidez; a segunda categoria, "expressão da maternidade" reuniu os significados atribuídos à maternidade $e$ as dificuldades enfrentadas. A terceira "implicações da maternidade no cotidiano" referem-se ao enfrentamento do processo saúde-doença e ao relacionamento familiar. $\mathrm{Na}$ análise das categorias foram identificados elementos potencializadores e protetores da vulnerabilidade à infecção, adoecimento e morte pelo HIV no contexto de transmissão vertical do HIV. Concluiu-se que a maternidade, na ótica das mulheres, constituiu-se em um evento protetor da vulnerabilidade ao adoecimento e morte por HIV, sendo assim necessária uma abordagem dessas mulheres sobre o desejo de ter filhos, pois a maternidade possibilita resignificar suas vidas.

Descritores: Síndrome de Imunodeficiência Adquirida, Mães (Transmissão), Doenças Transmissíveis (HIV). 


\begin{abstract}
When women who are infected by AIDS get pregnant, they face several difficulties such as the fear of vertical transmission. The objective of this study is to identify the socio-demographic and living and work conditions in the life of women who have AIDS; idenfify the meaning atributed by them to maternity and identify the implications of being a mother in the health-disease process. It consists of an exploratory and quantitative study with 16 AIDS infected women, enrolled in a specialized service in STD/AIDS in the city of São Paulo. The data collected from clinical records and interviews from semi-structured guidelines, were later submitted to the content analysis, and interpreted according to the Vulnerability concept. The characteristics of the women studied are: single, reproductive age group, low education and precarious life condition, sexually infected, with late diagnostic. From de meaning of maternity three categories stood out: the first, "the pregnancy experience", including the determinants, the feelings and the pregnancy consequences: the second category, "maternity significance", combined the meanings attributed to maternity and the difficulties encountered. The third "daily implications of maternity" is related to the confront of the health-disease processand family relationship. While anayzing the categories, potencial elements, protectors against the vinerability to infection, falling ill and death caused by HIV in vertical HIV transmission, were identified. We concluded that maternity, from the women's point of view, was a protective event against the vulnerability to illness and death caused by the HIV. Therefore, it is necessary to approach these women to discuss the willingness of having children, because maternity makes it possible for them to redirect their lives.
\end{abstract}

Describers: Syndrome of Acquired Immunodeficency, Mothers (Transmission), Transmissible Diseases (HIV). 


\section{Lista de Quadros}

Quadro 1 - Distribuição das mulheres entrevistadas quanto à idade, escolaridade, cor, estado civil, ocupação, renda familiar, número de pessoas na família e casa. São Paulo - SP, 2005.....61 61

Quadro 2 - Distribuição de mulheres segundo local e tempo de diagnóstico, tempo de matrícula e adesão ao tratamento. São Paulo - SP, 2005.

Quadro 3 - Distribuição de mulheres segundo idade, número de filhos pré e pós diagnóstico de aids, situação atual, idade e diagnóstico dos filhos. São Paulo-SP, 2005. 
Lista de abreviatura e siglas

$\begin{array}{lll}\text { AIDS } & - & \text { Síndrome da Imunodeficiência Adquirida } \\ \text { ARVs } & - & \text { Medicamentos anti-retrovirais } \\ \text { AZT } & - & \text { Zidovudina } \\ \text { CD4 } & - & \text { Linfócito T-Helper } \\ \text { DST } & - & \text { Doença Sexualmente Transmissível } \\ \text { HIV } & - & \text { vírus da imunodeficiência humana } \\ \text { HPV } & - & \text { vírus do Papiloma Humano } \\ \text { NIC } & - & \text { Neoplasia Intra-epitelial Cervical } \\ \text { PAS } & - & \text { Programa Assistência Saúde } \\ \text { SAE } & - & \text { Serviço Assistência Especializada } \\ \text { TV } & - & \text { Transmissão Vertical } \\ \text { UBS } & - & \text { Unidade Básica de Saúde } \\ \text { UDI } & - & \text { Usuário de Drogas Injetáveis }\end{array}$




\section{Sumário}

Dedicatória ................................................................................................ IV

Agradecimentos ................................................................................ V

Resumo (...................................................................................... VII

Abstract

Lista de Quadros....................................................................................... IX

Lista de abreviatura e siglas ......................................................................

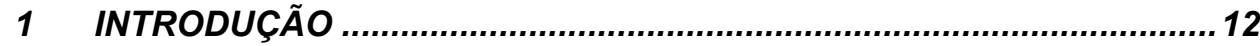

$1.1 \quad$ Apresentação..........................................................

1.2 A epidemia da aids no segmento feminino ........................16

1.3 A transmissão materno-infantil do HIV ............................20

$1.4 \quad$ Cotejando estudos sobre o tema ..................................25

$1.5 \quad$ Problematizando o objeto de estudo ............................... 31

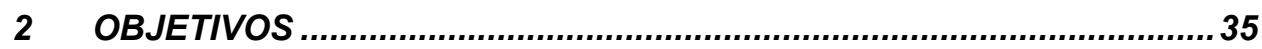

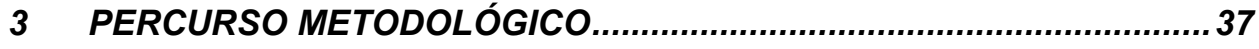

3.1 Marco Referencial...................................................... 38

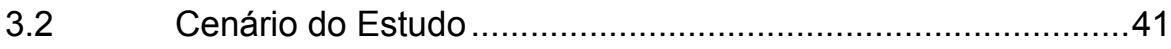

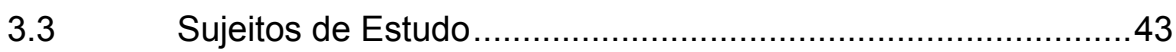

3.4 Instrumentos e procedimentos para coleta de dados .............44

3.5 Organização dos dados para análise ..............................46

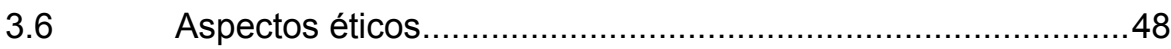

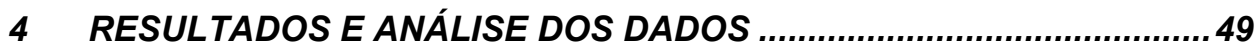

4.1 Conhecendo as mulheres .......................................... 50

4.2 Caracterização sócio-demográfica, clínica e das condições de vida das mulheres com aids .....................................58

4.3 Conhecendo os significados de ser mãe ........................73

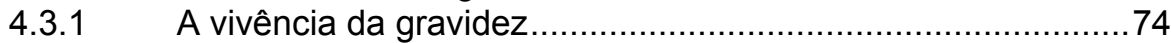

4.3.2 A expressão da maternidade ..................................... 94

4.3.3 As Implicações da maternidade no cotidiano das mulheres .. 103

5 CONSIDERAÇÕES FINAIS ............................................................ 110

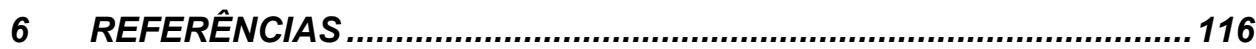

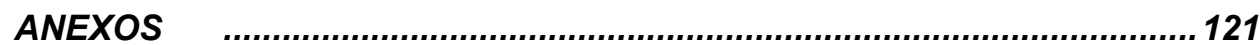

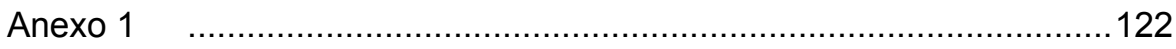

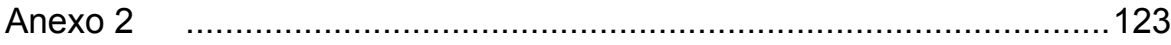

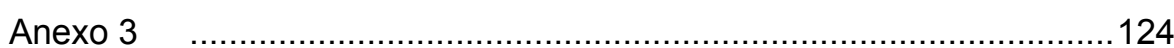




\section{Introdução}

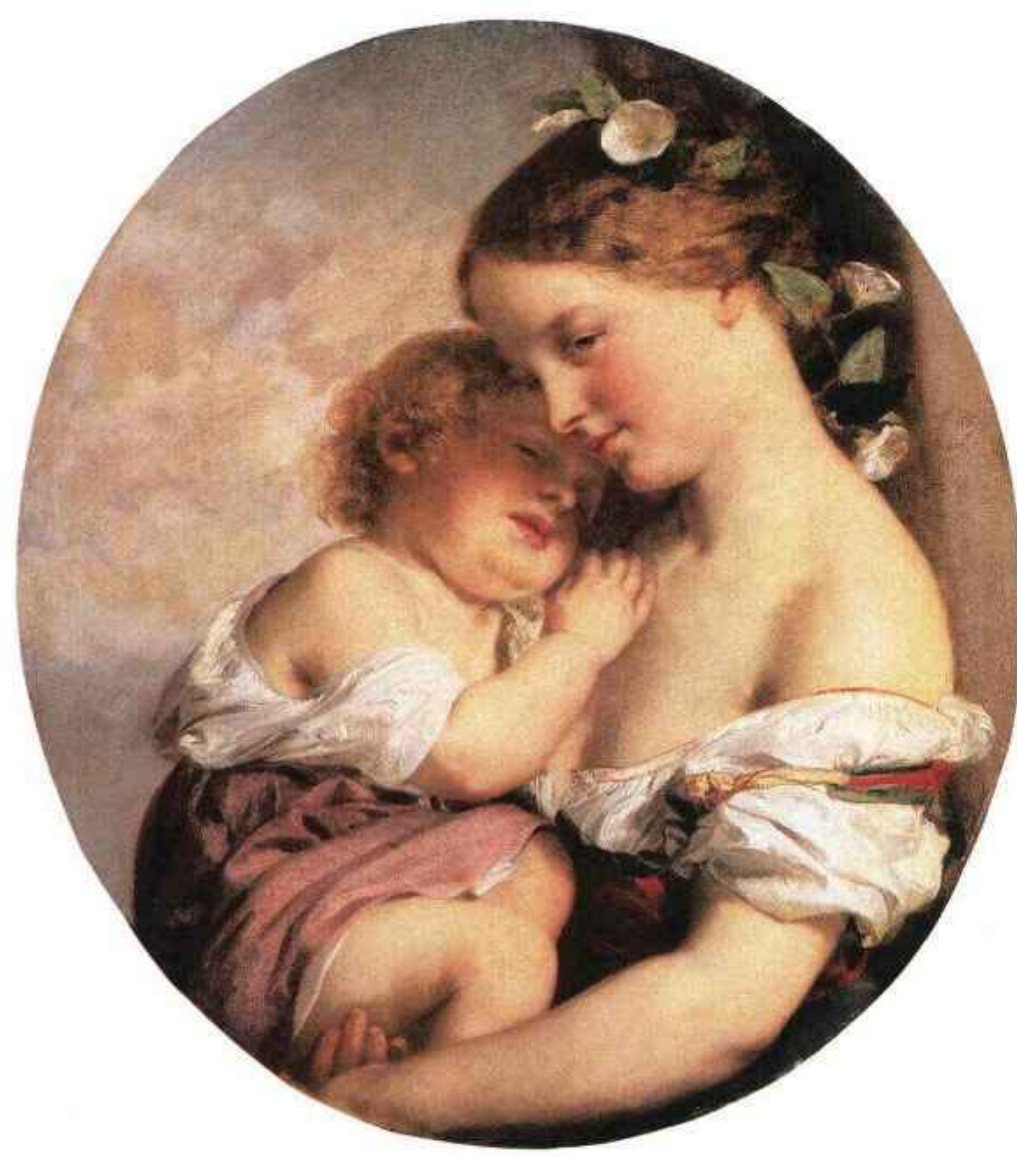

"O princípio requer liberdade de gosto e busca, de estruturar o plano de vida que se ajuste à sua personalidade, de fazer 0 que se quer, de se sujeitar às conseqüências, sem impedimento por parte das criaturas iguais a mim, contanto que o que fizermos não as prejudique, mesmo que achem a nossa conduta insensata, perversa ou errada." (John Stuart Mill) 


\section{$1.1 \quad$ Apresentação}

Um dos desafios dos últimos vinte anos no campo da saúde tem sido a luta contra a aids e danos que provoca no ser humano. Pelas suas características epidemiológicas, pelo estigma a ela atrelado, pelas formas de transmissão - em especial a sexual -, essa síndrome tem diversos desdobramentos que afetam o psiquismo, o comportamento social e a qualidade de vida do portador de aids.

Uma das facetas sombrias da doença é que as mulheres infectadas pelo vírus da imunodeficiência adquirida (HIV), matrizes que são, enfrentam múltiplas dificuldades ao se tornarem gestantes e, depois, defrontam-se com mais problemas para criar seus filhos, especialmente o receio de transmissão vertical por HIV.

A sociedade, na pessoa de amigos, colegas de trabalho, profissionais da área de saúde, nem sempre aprova a gestação em mulheres soropositivas ao HIV. Contudo, as adversidades não as desestimulam e tampouco as levam a abdicar dos seus sonhos com a maternidade. 
A despeito do pouco acolhimento, dos anseios, dos medos e culpas, das discriminações com que se defrontam em seus caminhos, essas mulheres guerreiras dão concretude aos seus sonhos.

A aproximação com a temática da gravidez em mulheres com HIV decorre da minha trajetória profissional em um Serviço Ambulatorial Especializado (SAE) no atendimento de pessoas portadoras de doenças sexualmente transmissíveis e/ou com aids (DST/AIDS), por um período de 18 anos.

Em 1988, iniciei minhas atividades profissionais como enfermeira em uma Unidade Básica de Saúde da Cidade Líder, ocasião em que se iniciou, nesse serviço, o atendimento de pessoas soropositivas ao HIV.

Em 1992, passei a atuar como supervisora das unidades de saúde que desenvolviam atividades do Programa Municipal de DST/AIDS, na regional Itaquera.

Em 1996, com a implantação do Programa de Assistência à Saúde (PAS), instituída pelo governo municipal na cidade de São Paulo, retornei para a Unidade Básica de Saúde, já transformada em um SAE, como educadora em saúde pública. Nessa ocasião, foi criado nesse serviço um Setor de Pesquisa, responsável pela sistematização das informações existentes e produção de dados para auxiliar a realização de diagnósticos, de avaliações e planejamento. 
Em 2000, durante o desenvolvimento de um projeto sobre a transmissão vertical do HIV no SAE, verificou-se que havia um número expressivo de mulheres com aids que engravidavam. O exame dos prontuários clínicos das crianças soropositivas mostrou que essas mulheres tinham uma freqüência irregular nas atividades relativas ao pré-natal das mães. Despertou a atenção da equipe o fato de essas mulheres estarem em acompanhamento nesse SAE quando ocorreu a gravidez. Apesar da adoção do protocolo vigente para diminuição dos riscos da transmissão vertical e mesmo com a disponibilidade de o pré-natal ser feito em um serviço especializado, não foi possível evitar a transmissão vertical do HIV em várias crianças.

É inegável que a ocorrência da infecção pelo HIV na transmissão vertical tem condicionantes de diversas ordens, tais como: condições sócio-econômicas, percepções e perspectivas da própria mulher, informações e orientações sobre a doença, entre outros. Percebia-se no discurso dos profissionais, que havia um território existencial dessas mulheres no tocante à maternidade, envolvendo aspectos subjetivos, que não estava suficientemente esclarecido. Nesse contexto, nasceram alguns questionamentos que deram origem ao presente estudo: o que leva uma mulher com aids a engravidar? Qual o significado da maternidade para essas mulheres? Como é cuidar de si e de uma criança, sendo portadora de uma doença como a aids? 


\subsection{A epidemia da aids no segmento feminino}

A análise da epidemia de aids no Brasil revela uma tendência à estabilização, embora ainda em patamares elevados, pois em 2003 foram diagnosticados 32.247 casos novos, que equivalem a uma taxa de incidência 18,4 casos por 100 mil habitantes. Entre os anos de 1980 e 2004, foi registrado um total de 362.364 casos no País.

Os dados epidemiológicos mostram que a aids continua sendo um dos agravos de relevância em nosso País, em especial para o grupo de mulheres.

Uma análise mais cuidadosa dos dados revela que a tendência à estabilização da epidemia de aids pode ser observada apenas no segmento masculino, cuja taxa de incidência em 2003 foi de 22,8 casos por 100 mil, menor do que a observada em 1998, de 26,4 por 100 mil (BOLETIM, 2004b).

Desde 1998, verifica-se uma estabilização na taxa de mortalidade por aids no país, que pode ser atribuída à melhoria dos recursos existentes e disponíveis para diagnóstico e tratamento (BOLETIM, 2003b).Enquanto nos homens a taxa de mortalidade de 8,8 por 100 mil habitantes se manteve nos últimos três anos, nas mulheres há pequeno aumento, sendo 3,9 em 2001 e 2002 e, 4,0 em 2003. (BOLETIM, 2004b) 
Apesar das várias iniciativas, a partir do início dos anos 90, de serviços comunitários relacionandos ou não à aids de organizações atreladas à saúde da mulher e de políticas e programas governamentais de largo alcance, a epidemia de aids, entre as mulheres no Brasil, continua a crescer.

Desde 1992, a disseminação do HIV no segmento feminino vem assumindo maior importância em decorrência do aumento do número de casos na subcategoria de exposição heterossexual.

No Brasil, durante duas décadas da epidemia de aids, de 1983 a 2003 , foram notificados 89.527 casos em mulheres, representando $28,8 \%$ do total de casos. A maior taxa de incidência em mulheres pode ser verificada no ano de 2003: 14,0 casos por 100 mil (BOLETIM, 2003b). No início da epidemia, apenas 5,0\% dos casos de aids notificados eram do sexo feminino. Até 2001, $70 \%$ do total de casos notificados ocorreram em mulheres e foram diagnosticados após 1992 (BRASIL, 2001a).

Até 1999, a faixa etária entre 20 e 49 anos constituía o grupo mais acometido por essa síndrome, tanto para o sexo masculino como para o feminino. Posteriormente, observa-se uma tendência ao aumento do número de casos em faixas etárias mais avançadas (BOLETIM, 2003b).

Verifica-se ainda que desde o início da epidemia, a via sexual (heterossexual) permanece como a categoria de transmissão mais freqüente $(86,9 \%)$ em todo o país no sexo feminino, sendo nítido o aumento no decorrer dos anos, pois em 1992 correspondia a $70,7 \%$ dos casos notificados e em 2003 passou para 93,5\% (BOLETIM, 2003b). 
No Estado de São Paulo, no ano de 1998 ocorreu o maior número de notificações de aids em mulheres, 3920 casos, sendo o coeficiente de incidência de 21,57 casos para 100.000. Em 2002 houve uma redução, com 3053 casos notificados de aids, correspondendo a 15,69 casos para cada 100.000 mulheres (BOLETIM, 2004a).

A queda da mortalidade, no Estado de São Paulo, começa a ser evidenciada a partir de 1996. Embora com menor impacto do que nos anos anteriores, a aids ainda figura entre as principais causas de mortalidade dos adultos jovens, sendo responsável por $1,5 \%$ das mortes ocorridas no Estado de São Paulo nessa faixa etária. Nas mulheres, a aids, atualmente, é a décima quinta causa de morte.

Nos anos de 1995 e 1996, a taxa de mortalidade por aids em mulheres, no Estado de São Paulo, alcançou o valor máximo em toda a epidemia, 10,99 por 100.000 habitantes, e mesmo assim correspondeu a um terço daquela verificada na população masculina (BOLETIM, 2004a).

Até 2003, na cidade de São Paulo foram notificados 55.772 casos de aids, correspondendo aproximadamente a $20 \%$ do total de casos no país. Nos anos de 2001 e 2002, observa-se uma tendência à diminuição da taxa de incidência, sendo 32 e 28 casos por 100 mil habitantes, respectivamente (BOLETIM, 2003a).

No município de São Paulo, observa-se uma tendência de queda da mortalidade em ambos os sexos, provavelmente como uma decorrência do maior número de serviços especializados em DST/AIDS. O que contribui para a melhoria do acesso aos recursos de diagnóstico e terapêutico 
do que em outros estados. (BOLETIM, 2003a; BOLETIM 2004a). A redução significativa no número absoluto de óbitos é observada entre 1996 e 1998 (TEIXEIRA; PAIVA; SHIMMA; 2000).

Observam-se mudanças em outras características das mulheres com aids, como o grau de escolaridade e as condições econômicas. No Brasil e no município de São Paulo, a doença atinge mais mulheres com menor grau de instrução, entre 1 e 7 anos de escolaridade (54,4\%) (BOLETIM, 2003b).

No Estado de São Paulo, a partir de 1994, as mulheres notificadas com aids apresentaram escolaridade persistentemente mais baixa do que os homens, sendo maior o número de mulheres sem instrução, fato este que pode ser associado, ainda que indiretamente, à maior pauperização da epidemia no sexo feminino. (BOLETIM, 2001)

No Estado de São Paulo, de 1980 até junho de 2005, foram notificados 40.264 casos de aids em mulheres, que equivale a $28,9 \%$ do total de notificações. Houve uma maior incidência nos anos de 1997 e 1998, e no período de meados da década de 90 a 2003 ocorreu uma diminuição de cerca de 1,5 vezes entre as mulheres. A relação masculino:feminino permanece 2:1 diferente do início da epidemia de 27:1 (BOLETIM, 2005) .

Semelhantemente à evolução do conhecimento técnicocientífico em aids, os recursos atualmente disponíveis para a sua prevenção e controle contribuíram para que ocorressem mudanças no processo de adoecimento e morte pela aids. Dentre elas, destaca-se o aumento do tempo de sobrevida da pessoa infectada pelo HIVIAIDS, o que requer intervenções 
que levem em consideração essa nova condição. (SHIMMA, 2003). Marins et al (2003) demonstraram que a utilização da terapêutica medicamentosa disponível atualmente tem aumentado o tempo de sobrevida de pessoas soropositivas ao HIVIAIDS de maneira admirável. Em 1980, o tempo médio de sobrevida da pessoa com aids, era de cinco meses, já em 1995 houve uma elevação desse tempo de 13 meses e, para aqueles diagnosticados em 1996, a sobrevida encontrada foi de 58 meses.

\begin{abstract}
A descrição do cenário da epidemia da aids evidencia mudanças nos perfis epidemiológicos, demandando intervenções que contemplem, por um lado, as características atuais das pessoas infectadas ou de grupos vulneráveis à infecção pelo HIV. Por outro, contemplem as conseqüências dessas mudanças, como o aumento da transmissão vertical do HIV em decorrência da feminilização da epidemia.
\end{abstract}

\title{
1.3 A transmissão materno-infantil do HIV
}

O aumento do número de casos de aids no segmento infantil, ocorridos pela transmissão vertical (TV) do HIV, representa uma das conseqüências mais danosas do fenômeno da feminilização da aids.

O risco de infecção pelo HIV intra-útero é de $35 \%$, enquanto durante o trabalho de parto e, no parto propriamente dito, a transmissão do HIV é responsável por cerca de $65 \%$ dos casos de soropositividade ao vírus em recém-nascidos. (SÃO PAULO, 2004). O aleitamento materno representa um risco adicional de 22,0\% para ocorrência de Transmissão Vertical. Estima-se, 
com base em estudos sentinela realizados em maternidade, uma prevalência de 0,6 de infecção pelo HIV entre as parturientes. (DEL BIANCO, 2003). Além destas, são conhecidas outras condições que contribuem com a ocorrência da TV: carga viral materna, ruptura prematura das membranas, prematuridade fetal e manobras obstétricas. (SÃO PAULO, 2004)

O aumento da ocorrência de casos no sexo feminino em idade reprodutiva reflete-se no aumento anual da frequência da transmissão maternoinfantil do HIV. No período entre 1984 e 1987, no Brasil, essa modalidade de transmissão foi responsável por cerca de $22,0 \%$ dos casos, passando para $82,0 \%$ em 2001 , o que equivale a $2,8 \%$ do total de casos notificados com aids. (BRASIL, 2001a)

Em nosso País, a TV do HIV tem sido responsável por cerca de $80 \%$ dos casos notificados de aids em menores de 13 anos. Até dezembro de 2003, foram notificados 10.177 casos nesta faixa etária, correspondendo a $3,4 \%$ do total de casos ocorridos no Brasil. (SÃO PAULO, 2004). Atualmente, a transmissão vertical é a via de transmissão mais freqüente $(83,6 \%)$ no segmento infantil. (BOLETIM, 2003b)

Vale destacar que a categoria de exposição sanguínea vem decrescendo ao longo do tempo, de 9,2\% dos casos em 1992, para nenhum caso desde 2002, em conseqüência do controle do sangue e hemoderivados, oferecidos pelos hemocentros.(BOLETIM, 2003b)

No estado de São Paulo, na análise de vinte anos de epidemia, de 1980 a 2000, verifica-se uma nítida tendência de queda do número de infecções pelo HIV em crianças, residentes nos seguintes municípios: São 
Paulo, Franco da Rocha, São José dos Campos e Taubaté. Já outras três cidades, Osasco, Mogi das Cruzes e Campinas, apresentam discreto aumento no número de casos; e nos demais municípios se observa uma tendência à estabilização. O uso de antiretrovirais, assim como o aprimoramento das ações de prevenção e controle da transmissão materno-infantil provavelmente são responsáveis pela diminuição dos coeficientes de incidência (BOLETIM, 2001).

No Estado de São Paulo, desde o início da epidemia, a TV é a forma de exposição mais freqüente, correspondendo a $85 \%$ dos casos ocorridos no segmento infantil. Desde 2001, não há relato de casos derivados de transfusão sanguínea. A via sexual ou uso de drogas injetáveis, na faixa etária de menores de 13 anos, não foram igualmente importantes; em quase $15 \%$ dos casos a forma de exposição era ignorada ou ainda estavam sob investigação do HIV (BOLETIM, 2005).

Em 2001, no município de São Paulo, foram notificados 75 casos de aids por TV e em 2002, 43 casos, ou seja: houve uma queda da transmissão vertical de 7,0 para 4,0 (BOLETIM, 2003a). Essa queda pode ser atribuída à política para a prevenção e controle das DST/AIDS, cujas ações estão direcionadas para a melhoria da assistência à gestante no pré-natal, no parto e ao recém-nascido. Acresce-se a essas medidas de prevenção da TV, as capacitações técnicas dos profissionais da área de saúde, bem como o estabelecimento de portarias que instituem medidas visando à redução da infecção em bebês como por exemplo, a obrigatoriedade do teste rápido para o diagnóstico sorológico do HIV em maternidades. 
Nos primeiros anos da década de 50, foram desenvolvidos estudos sobre o uso do Zidovudina (AZT) em mulheres gestantes, que demonstraram a diminuição do risco da TV do HIV. (BRASIL, 2001a)

O êxito alcançado na prevenção do TV pelo protocolo Aids Clinical Trials Gruoups Protocol 076 (ACTG 076) desencadeou, no Brasil, a distribição gratuita do AZT oral para getantes, desde 1994, e em 1996, do AZT injetável na hora do parto e do AZT oral para os recém-nascidos. (BRASIL, 2001a)

No Estado de São Paulo, embora a distribuição do Zidovudina (AZT) oral e outros ARV, como terapêutica preventiva da TV, tenha se iniciado em 1991, efetivamente o acesso ocorreu somente após 1996.

Em 2001, as recomendações para a terapia anti-retroviral (TARV) em gestantes, associada às demais condutas profiláticas da TV do HIV, foram atualizadas e incorporado o uso de outros ARV, tendo em vista a ampla comprovação de que seu uso combinado AZT e outros ARV, segundo avaliação clinica e laboratorial, como contagem de níveis de CD4 + carga viral, é capaz de reduzir significativamente a carga viral do HIV para níveis indetectáveis, resultando na queda das taxas de transmissão materno-infantil para níveis inferiores a 3\%.(BRASIL, 2001a). O AZT injetável para as parturientes, a terapia combinada com antiretrovirais (TARD) e o AZT solução oral para todos recém-nascidos expostos ao HIV se tornou acessível somente depois de 2001 no Brasil (BOLETIM, 2003b)

Além da quimioprofilaxia, outras medidas preventivas da TV do HIV estão disponíveis nos serviços especializados em DST/AIDS, tais como: 
oferecimento universal do teste sorológico para o diagnóstico do HIV às gestantes no pré natal, oferta do leite artificial ou leite pasteurizado em banco de leite, em substituição ao aleitamento materno (BOLETIM, 1999).

Estima-se que, com a adoção de medidas de prevenção e controle à TV, a taxa de transmissão vertical tecnicamente possível permaneça ao redor de 2,0\%, alcançadas em poucos países desenvolvidos. (BOLETIM, 2003b)

O uso adequado dos ARV e o desenvolvimento de ações de prevenção a TV do HIV modificaram, efetivamente, o cenário da epidemia da aids no segmento infantil. No entanto, crianças continuam sendo infectadas, necessitando de acompanhamento mensal em um serviço de saúde visando à avaliação sistemática do seu crescimento e desenvolvimento e avaliação da ocorrência da TV do HIV. A atenção que as crianças expostas ao HIV requer, em especial, durante os primeiros dezoito meses de vida, nos levaram a uma das investigações deste estudo: nas mulheres com aids, o cuidar dos filhos, devido à exposição do HIV, interfere no cuidado consigo própria?

A prevenção da transmissão vertical do HIV é, para os serviços de saúde, uma das principais ações do Programa de Prevenção e Controle das DST/AIDS, mas para as mulheres com HIV, pode ou não ser uma necessidade, pois a realização de algumas dessas medidas, muitas vezes extrapola suas decisões e possibilidades de concretização, face à emergência de anseios e sentimentos que fogem ao seu controle, como o desejo de ser mãe. (SILVA, 2003) 


\subsection{Cotejando estudos sobre o tema}

Ao buscar referências para o tema - significados de ser mãe no contexto da aids - foram encontrados estudos significativos que enriqueceram a problematização desta pesquisa.

Serão destacados os estudos que estão circunscritos às seguintes dimensões: primeiramente, a do conhecimento da mulher no que se refere à própria vulnerabilidade, quanto ao acesso às informações e sua autonomia para decidir sobre ser mãe. Em segundo lugar, a dimensão da organização dos serviços de saúde nos aspectos da atenção, isto é, o atendimento às necessidades das mulheres, acolhimento e o acesso aos serviços de saúde. Em terceiro, tratar-se-á das políticas de saúde: a disponibilidade de informações, a acessibilidade à medicação e a exames laboratoriais.

Silva (2003), em seu estudo realizado com pacientes de um SAE DST/AIDS no município de São Paulo, teve como objetivo compreender como o risco da transmissão vertical, tanto nas políticas quanto nas práticas dos profissionais de saúde, é apreendido e re-significado pelas pessoas convivendo com HIVIAIDS na construção de suas decisões reprodutivas. A população amostra consistiu de 8 usuários, sendo 6 mulheres e dois homens. Os resultados indicaram que as questões reprodutivas não são problematizadas no espaço dos serviços de saúde pelos usuários nem pelos profissionais de saúde. Isso se reflete em um silêncio, cuja cumplicidade é compartilhada por ambas as partes. "Tal silêncio, que parece um descaso com 
a vida reprodutiva, pode ser interpretado, de um lado, como uma forma de 'esquecer' da soropositividade, de outro, como um evento do mundo da vida [..." (SILVA 2003, p.3).

O estudo de Ruggiero (2000), com 13 gestantes portadoras do virus HIV realizado em três UBS's da cidade de São Carlos-SP, teve como objetivo conhecer o significado da gravidez. Os resultados apontam que as gestantes não tem pleno conhecimento da sua doença, carregam conflitos de vida e morte em relação a si próprias e aos filhos, são vulneráveis à contaminação e sentem-se culpadas.

Zihlmann (2005) realizou estudo com 15 mulheres vivendo com HIVIAIDS, freqüentadoras de uma associação voluntária a portadores de aids e de um hospital de infectologia, ambos na cidade de São Paulo. O objetivo central foi conhecer como elas percebiam e atribuíam sentido às suas decisões reprodutivas. As depoentes sinalizaram alguns acontecimentos decorrentes da gravidez: reorganização de sua vida pessoal, obtenção de suportes familiares e institucionais adicionais, bom acolhimento e seguimento para profilaxia da transmissão materno-infantil por parte da equipe de atendimento especializado.

O estudo de Sherlock; Vieira (1999), realizado com mães soropositivas ao HIV, que acompanham seus filhos em um ambulatório especializado em DST/AIDS, em Fortaleza-Ce, teve o objetivo de explorar os sentimentos e as expectativas das mães que se confrontam com a possibilidade de seus filhos serem portadores de HIV e que implicações isso pode ter no processo de cuidado. Os resultados testemunham que o medo dessas mulheres de que a criança adoeça ou pereça favorece o abandono do 
controle de sua saúde, ao priorizar o cuidado com a saúde da criança, evidenciando a sua valorização à maternidade e a irrelevância que o seu estado de soropositividade ao HIVIAIDS passa a ter nesse cenário.

Moura (2004), no estudo realizado com 14 mulheres no município de São Paulo, objetivando identificar a percepção, as expectativas e ações da gestante soropositiva ao HIV, quanto ao filho que estava gerando, pôde concluir pelas verbalizações dos sujeitos da pesquisa que, muitas vezes, o ato de engravidar nessas mulheres é interpretado como uma prática irresponsável, por expor voluntariamente o feto ao HIV. Foram relatadas atitudes de discriminação por parte dos profissionais dos serviços de saúde em que foi realizado o diagnóstico da gravidez ou da soropositividade, assim como por pessoas que pertenciam ao mesmo grupo social dessas mulheres. São comportamentos que contribuem para acentuar sentimentos de autoculpabilização nessas mulheres, experimentados durante a gravidez frente à possibilidade de transmitir o vírus ao feto

Na dimensão organização dos serviços de saúde, vem a propósito o trabalho de Oliveira; França Junior (2003), que estruturou seu estudo a partir de observações da rotina dos profissionais de SAEs em DST/AIDS de São Paulo, colhendo depoimentos de usuários e de profissionais, com o objetivo de compreender o modo como foram tratadas as demandas reprodutivas das pessoas vivendo com HIVIAIDS. As conclusões demonstraram que os trabalhadores dos serviços de saúde não incorporam as demandas reprodutivas como uma necessidade dos usuários. Isso é corroborado pela fala de uma usuária que reivindica ser acolhida como alguém que quer partilhar outros aspectos de sua vida. 
O estudo de Aguiar (2004), realizado com 13 mulheres portadoras do HIV e 7 profissionais de saúde, na cidade do Rio de Janeiro, visando compreender a relação entre o serviço e as usuárias soropositivas ao HIV em torno do tratamento a elas oferecido, traz subsídios para reflexões sobre a dimensão programática da vulnerabilidade. Sua análise revelou que os profissionais utilizam várias estratégias para adequar a assistência à precariedade dos recursos, tanto da instituição quanto das pacientes. Apesar das dificuldades encontradas, prevaleceu a busca por uma assistência o mais integral possível, para essa mulheres. Contudo permaneceu no imaginário desses profissionais a tradicional figura de mulher / mãe / esposa, vista como vítima. Por outro lado, as entrevistadas viam a si mesmas como "guerreiras", imagem figurada alimentada pela ideologia de mulher moderna, "produtora da esfera pública e privada, encobrindo a dupla jornada de trabalho como um dos efeitos de transição de gênero". Como pacientes, essas mulheres assumiam posturas ativas no seu tratamento por meio de múltiplas estratégias, como a reprodução do discurso médico. Elas também se tornam agentes ativos nas suas relações com os profissionais, estabelecendo limites para sua atuação e avaliando-os de acordo com a capacidade técnica e afetuosidade.

O estudo de Oliveira (2004) foi realizado em UBS da cidade de São Paulo, com 79 gestantes e 7 profissionais que as atendiam, individualmente ou em grupo, com o objetivo de caracterizar a dimensão programática da vulnerabilidade à infecção pelo HIV na perspectiva da transmissão vertical. Os resultados da pesquisa evidenciaram inadequação no desenvolvimento de ações preventivas da transmissão do HIV no pré-natal: realização tardia e, muitas vezes, sem aconselhamento pré e pós-teste 
sorológico ao HIV e insegurança por parte dos profissionais na abordagem das gestantes sobre a temática DST/AIDS. Reportando-nos novamente a Ruggiero, nos depoimentos das suas entrevistadas, transpareceu a inadequação das respostas institucionais a elas.

Landroni (2004), em seu estudo qualitativo com 14 mulheres portadoras de HIV, em um SAE DST/AIDS de São Paulo, com o objetivo de buscar compreender como o cuidado pode ser incorporado nas práticas assistenciais e contribuir na prevenção da transmissão vertical, verificou como as práticas assistenciais interditam a participação das mulheres como sujeito da ação e uma prática assistencial aleatória.

Knauth et. al. (2002), em seu estudo com 60 gestantes soropositivas ao HIV residentes em São Paulo-SP ou em Porto Alegre-RS, constatou que há uma inadequação na maneira de conduzir o pré-natal das gestantes portadoras de aids, no que se refere à opção pelo tipo de parto e pela esterilização. Segundo a autora, o fato de os profissionais de saúde prescreverem o tipo de parto e a esterilização, desconsiderando a vontade e as experiências das mulheres em partos precedentes, faz com que elas considerem essa gestação como mais difícil do que as anteriores e pior do que o esperado. Ressalte-se que, em muitos casos, elas eram convencidas pelo profissional que a acompanhava de que o parto cirúrgico evitaria a transmissão do vírus ao seu filho. Assim, o parto cesárea apresentava-se como a opção mais viável. A autora esclarece que, de acordo com os depoimentos, não havia uma orientação homogênea dos diversos serviços que atendem gestantes com HIV em relação ao tipo de parto, o que resultou em confrontos quanto às diferentes informações recebidas. 
Ruggiero (2000), em seus estudo já citado anteriormente realizado na cidade de São Carlos-SP, com 13 gestantes portadoras do HIV, sobre o significado que atribuem à gravidez, verificou também que as gestantes qualificam como bom o atendimento e a autora ressalta que nos serviços investigados era oferecida somente a consulta médica, demonstrando a necessidade de diversificar o atendimento para que haja uma comunicação mais efetiva, que facilite o encontro entre sujeitos.

No tocante à dimensão das políticas públicas voltadas para a prevenção da transmissão vertical do HIV, o número de experiências que consideram as especificidades da condição feminina é pequeno. Só nos últimos anos surgiram dados mais sistemáticos sobre as mulheres portadoras, que permitem promover programas especiais ou subsidiar a elaboração de políticas públicas mais sensíveis às necessidades das mulheres com HIV.

Conforme Zihlmann (2005), já mencionada anteriormente, no Brasil, há uma desarticulação entre os Programas vinculados à área da Saúde da Mulher e às DST/AIDS, abrangendo entraves relacionados à estrutura de inserção nos setores governamentais, independência dos recursos financeiros, não chegando à rede básica de saúde, o que enfraquece as ações preventivas.

Arilha (2002, p.9), ao estudar sobre as políticas públicas, menciona que dentre as ações preventivas, verifica-se as barreiras encontradas quanto ao acesso aos métodos contraceptivos e quanto a subsídios para que as mulheres façam escolhas livres e conscientes em relação às desigualdades de poder. Para essa autora, a dificuldade de acesso aos métodos de prevenção controlados (ou ao menos "iniciados") pelas 
mulheres deve-se à baixa disponibilidade de recursos, como os preservativos femininos. Conclui que nos últimos anos, a atenção concentrada na transmissão vertical cedeu lugar à discussão de várias questões no campo dos direitos reprodutivos. O método contraceptivo por meio de preservativo quase sempre está sob controle do homem, o que reduz a autonomia feminina dificultando a negociação nas decisões de prevenção e reprodução. "O avanço das dst/aids entre as mulheres é indicativo não apenas das dificuldades em oferecer respostas institucionais para contenção da epidemia, mas também pela situação de desigualdade de poder vivida pelas mulheres(...)."

Couto (2002 p.13), no estado do Rio de Janeiro, em seu estudo sobre os novos horizontes para as políticas públicas em HIVIAIDS, concluiu que:

O Brasil ainda não conseguiu delinear políticas governamentais para a intersecção pobreza-exclusão-aids. As prioridades públicas concentram-se em programas preventivos e assistenciais, nas áreas de saúde e educação. A inexistência da intersetorialidade, na elaboração das políticas públicas brasileiras compromete a resposta integral à dupla vulnerabilidade gerada pela superposição pobreza e aids,bem como a formulação de políticas específicas de proteção social que combinem saúde, assistência social e previdência para este grupo específico.

\subsection{Problematizando o objeto de estudo}

Os protocolos do Programa Saúde da Mulher determinam atendimentos segmentados em especialidades médicas, visando um corpo destituído de subjetividade, sem que haja troca de saberes entre o profissional 
e a usuária. Espera-se que este estudo contribua para que se repense a assitênica à mulher soropositiva ao HIV.

Segundo Parker e Galvão (1996), os movimentos feministas e de saúde da mulher exercem pressão sobre as autoridades brasileiras no sentido de implantarem programas integrados de saúde da mulher, principalmente, aqueles relativos à saúde reprodutiva, de maneira a atender de forma mais efetiva aos problemas ligados à desigualdade social e econômica de que padece a mulher na sociedade brasileira. A negação dos direitos reprodutivos e sexuais representa o âmago dos mais sérios problemas associados à saúde da mulher.

Diversos estudos mostram que o conhecimento de mulheres com aids sobre a transmissão materno-infantil é menor do que o esperado e que tanto a sexualidade como os direitos reprodutivos são temas pouco abordados na assistência a essas mulheres (PAIVA et al. 2002).

Landroni (2004,p.76) verificou que:

[...] as demandas trazidas pelas mulheres para o serviço no momento em que decidiram pela gravidez, bem como quando desejaram evitála e, até mesmo, diante da opção pela interrupção de uma gestação indesejada, não foram acolhidas, evidenciando dificuldades na incorporação da dimensão cuidadora nas práticas assistenciais.

Dias (1999:115-116), declara que os profissionais de saúde, na tentativa de compreender o que chamou de "incógnita da mulher soropositiva que engravida (...)", considera a gravidez uma escolha da mulher, pela qual é culpabilizada e descrevem a maternidade como uma experiência inerente a 
qualquer natureza feminina, da qual nem mesmo a mulher soropositiva ao HIV abdica.

Desde a década de 90, havia críticas às objeções de profissionais da área da saúde sobre a ocorrência da gravidez em mulheres soropositivas. Levine; Dubler (1990) afirmaram que tais objeções não consideram o contexto cultural-político-socioeconômico em que as decisões reprodutivas são produzidas, pautando-se em julgamentos morais para justificar pressões e coerções às mulheres em relação à tomada de decisão.

Arras (1990) avalia que a escolha pela maternidade constitui um dos dilemas morais vivenciados pelas mulheres soropositivas ao HIV, sendo em geral cercada por uma esperança no futuro, que se mostra envolta pela possibilidade da infecção, do adoecimento e morte da criança.

O estudo realizado por Cabral (1997) evidenciou que embora as mulheres com HIVIAIDS afirmassem que não deveriam ter engravidado, dada a possibilidade de ocorrer infecção na criança e de não poder amamentála, atribuindo à gravidez um sofrimento psíquico, ao se tornaram mães adquiriram maior vitalidade.

É necessário conhecer os significados que as mulheres com aids, que se tornam mães, atribuem à maternidade e as repercussões desta no controle do processo saúde-doença vivenciado, para subsidiar o planejamento de intervenções que levem em conta o olhar daquelas que são alvo das ações de prevenção da transmissão vertical do HIV, visando melhorar a qualidade da assistência a essas mulheres. 
No decorrer da leitura dos estudos citados anteriormente, vários questionamentos foram formulados: as mulheres soropositivas ao HIV conversam sobre a gravidez com os profissionais? Como a maternidade é interpretada pela mulher com HIV? A maternidade traz mudanças na vida da mulher com aids? Ser mãe é uma escolha para as mulheres com HIV? As mulheres que têm filhos antes e após o diagnóstico da aids percebem diferenças, entre essas duas condições, na vivência da maternidade? Como se dá o enfrentamento do processo saúde-doença após o nascimento dos filhos? Essas questões nortearam a elaboração de algumas hipóteses, descritas em seguida, que por sua vez orientaram a definição dos objetivos do estudo.

1. Considerando que a maternidade reflete expectativas sociais e culturais muito amplas, que surgem no imaginário social e estão ligadas à saúde, à felicidade, à construção da família e à continuidade da espécie, a sua vivência contribui para que a mulher soropositiva ao HIV atribua um novo significado a sua vida.

2. O exercício da maternidade em mulheres soropositivas ao HIV melhora o cuidado consigo própria, no tocante ao processo saúde doença .

3. A maternidade fortalece o enfrentamento do processo saúde-doença da mulher com HIV.

4. A maternidade não constitui um determinante da vulnerabilidade ao adoecimento e morte em mulheres com HIV. 


\section{Objetivos}

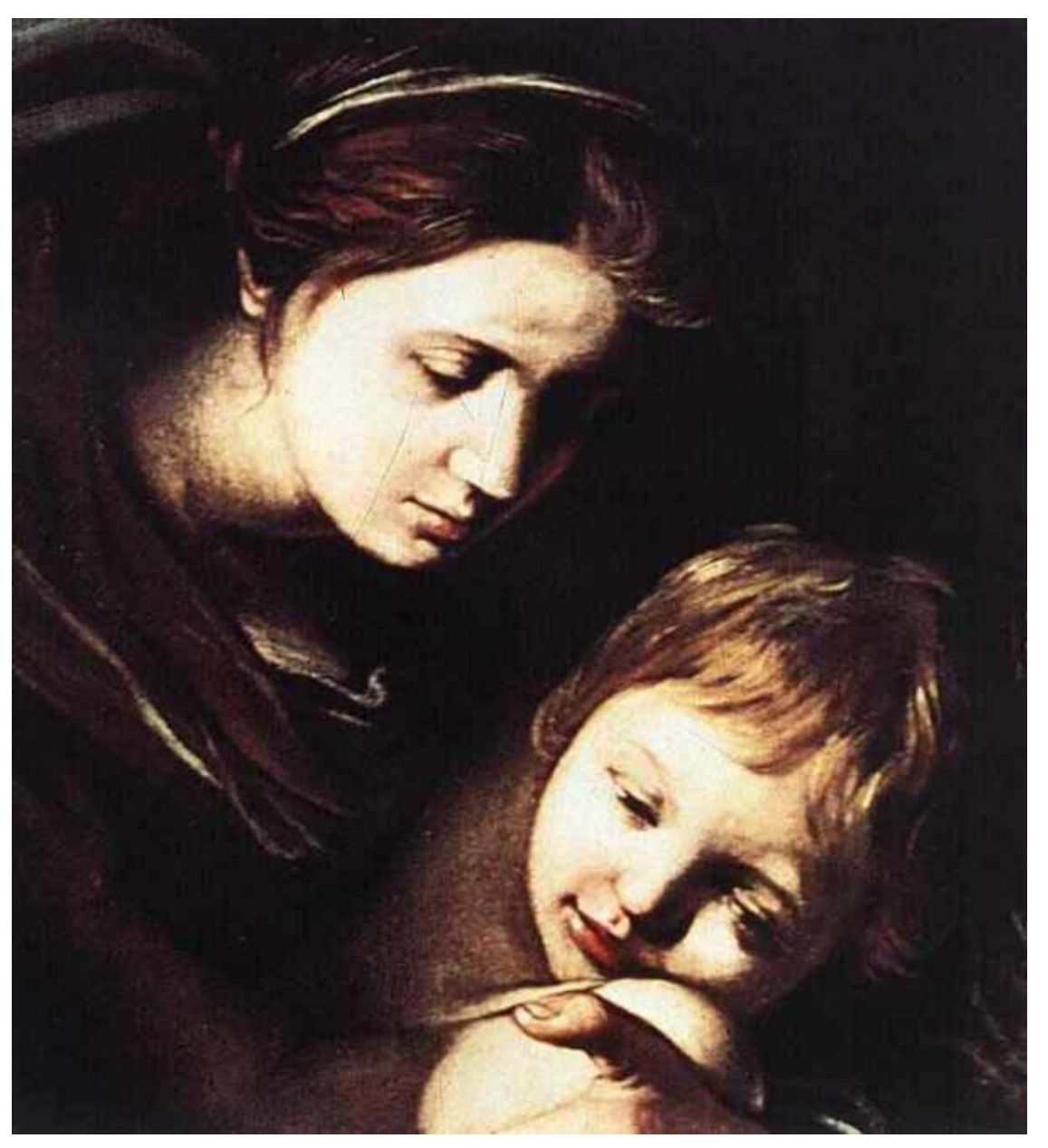

A maior de todas as coragens
é a de $^{\text {a desumir }}$
responsabilidades"
(Gustavo Barroso) 


\section{OBJETIVOS}

- Identificar algumas características sócio-demográficas e condições de vida e trabalho das mulheres com aids.

- Identificar os significados atribuídos à maternidade por mulheres com aids.

- Identificar as implicações de ser mãe no processo saúdedoença em mulheres com aids. 


\section{Percurso Metodológico}

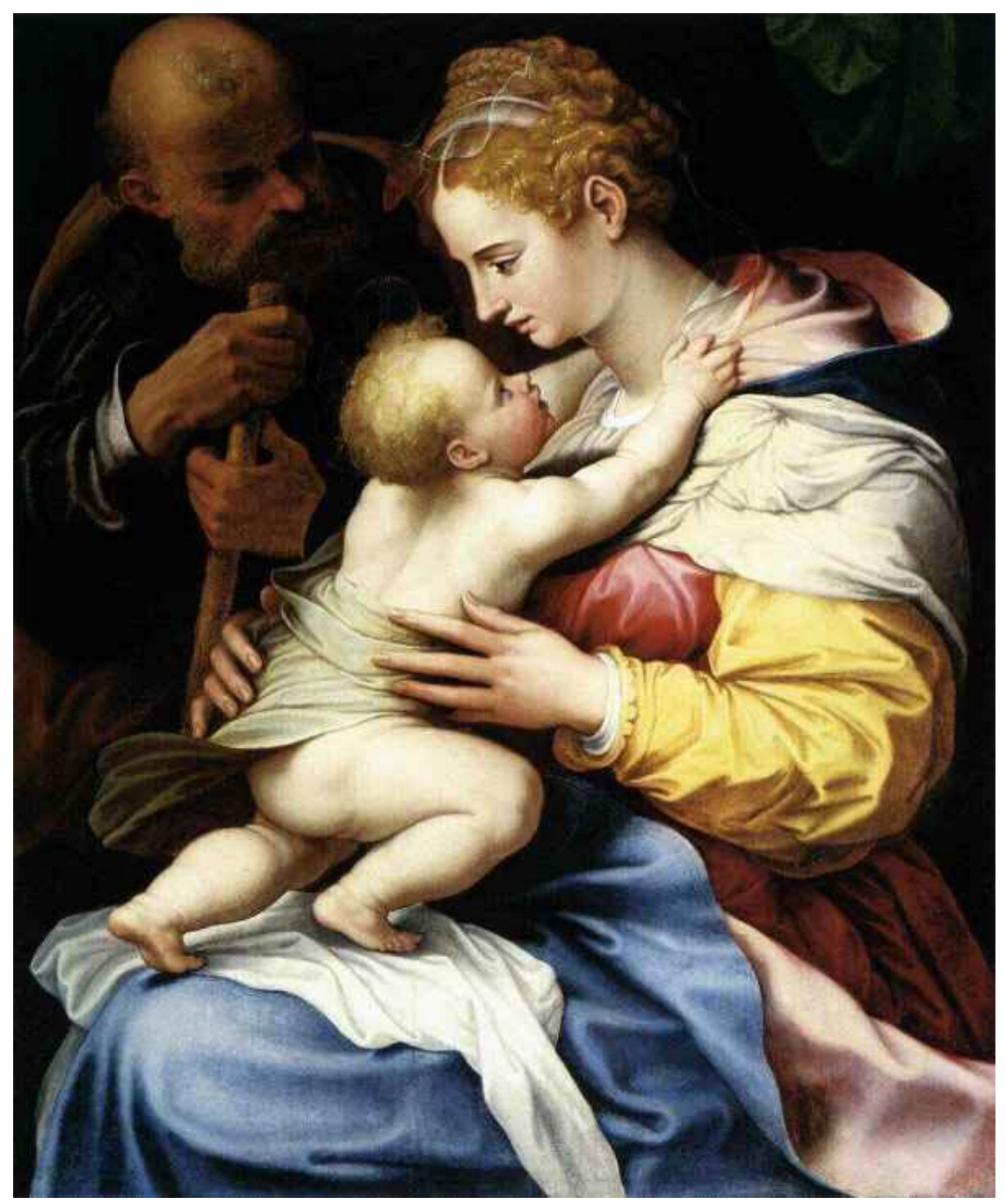

"É preciso respeitar e honrar as dificuldades: qualquer dificuldade é uma estrela, uma dificuldade invencível é um

sol"

(Paul Valéry) 
Trata-se de um estudo descritivo de natureza qualitativa. Optou-se por um estudo com abordagem qualitativa, por possibilitar a apreensão do universo de significações, motivos, aspirações, atitudes, crenças e valores, aspectos estes de difícil captação pelo método quantitativo. (MINAYO, 2004)

\subsection{Marco Referencial}

O referencial teórico utilizado para a realização deste estudo fundamenta-se no conceito de vulnerabilidade, apresentado originariamente por Mann; Tarantola; Netter (1993) e modificado, no Brasil, por Ayres et al. (1999).

Considera-se que vulnerabilidade, enquanto conceito, é um instrumento importante na busca da compreensão da infecção, do adoecimento e morte pelo HIV, por articular as questões individuais, as ações de controle desse agravo e a dimensão social, aspectos que condicionam a sua ocorrência e formas de expressão. Segundo Ayres et al. (1999, p.50), o conceito de vulnerabilidade configura:

[...] o esforço de produção e difusão de conhecimento, debate e ação sobre os diferentes graus e naturezas das suscetibilidades de indivíduos e coletividade à infecção, adoecimentos ou morte pelo HIV, segundo a particularidade de sua situação quanto ao conjunto integrado dos aspectos sociais, programáticos e individuais que os 
põem em relação com o problema e com os recursos para seu enfrentamento.

Ayres et al. (1999) ainda compreende a chance de exposição à infecção, adoecimento e morte pelo HIV, como resultado de aspectos que extrapolam o individual, agregando condições coletivas e contextuais, bem como os recursos disponíveis para a proteção dos suscetíveis.

O termo vulnerabilidade origina-se na área da advocacia internacional pelos Direitos Universais do Homem, designando grupos ou indivíduos fragilizados, jurídica ou politicamente, na promoção, proteção ou garantia de seus direitos de cidadania. Esse conceito é absorvido pelo campo da saúde a partir da publicação nos Estados Unidos, em 1992, do livro Aids in the World, parcialmente reeditado no Brasil em 1993.

A avaliação da vulnerabilidade à infecção,ao adoecimento e morte pelo HIV fornece critérios aplicáveis desde o auto-exame até o diagnóstico em nível nacional. Para a construção de diagnósticos de vulnerabilidade de indivíduos ou de grupos sociais, Ayres et al. (1999) propôs a operacionalização desse conceito por meio de três planos interdependentes: individual, programático e social, apresentados a seguir:

A vulnerabilidade individual engloba três dimensões: de ordem cognitiva (informação, consciência de problema e das formas de enfrentá-lo, a de ordem comportamental (interesse e habilidade para transformar atitudes e ações a partir daqueles elementos cognitivos), e a de ordem social (acesso a recursos e poder para adotar comportamentos protetores). (AYRES et al., 1999) 
A vulnerabilidade programática está voltada para o planejamento de programas de prevenção e controle em aids, desenvolvidos com execução no nível nacional, regional ou local. O plano programático da avaliação de vulnerabilidade permite a ligação entre os planos individual e social, por ser um aglutinador de informações, recursos materiais, suporte de várias ordens e um catalisador/amplificador das necessidades e contradições sociais. (AYRES et al., 1999)

A vulnerabilidade social compreende um plano extra-individual, em que se avalia a condição de uma coletividade. O acesso à educação e a informação disponível via meios de comunicação, a existência de serviços sociais e de saúde e alguns indicadores sociais, entre outros, integram essa dimensão da vulnerabilidade. (AYRES et al., 1999).

No conceito de vulnerabilidade estão implícitos fatores interdependentes e interatuantes mesclados e ativos em cada indivíduo, ou no coletivo, o tempo todo, não sendo possível separá-los.

Segundo Vilella (2005), a aplicação do conceito de vulnerabilidade à saúde resulta da busca de uma construção teórica que possibilita desvelar o processo de disseminação da epidemia no interior de grupos socialmente excluídos, por todos que militam contra a aids e lutam pelo reconhecimento e exercício dos direitos humanos das pessoas por ela acometida. Trata-se, portanto, de um conceito que possibilita a abordagem de comportamentos individuais, tendo em vista os fatores que os determinam, visando estimular a formação de propostas de enfrentamento que extrapolem o âmbito das ações sobre o indivíduo. 


\subsection{Cenário do Estudo}

Para um estudo que busca explorar a percepção das mulheres com aids quanto à relação entre estar com aids e ser mãe, considerou-se que o serviço de saúde, onde se dá o acompanhamento e assistência, e sua residência constituem os espaços mais apropriados para sua realização. Assim o cenário para o estudo foi o SAE, onde realizam o seu tratamento ou o domicílio.

A investigação foi desenvolvida em um Serviço Ambulatorial Especializado DST/AIDS (SAE DST/AIDS) da Secretaria Municipal da Saúde de São Paulo, situado no Bairro Cidade Líder, Coordenadoria de Saúde Leste, serviço especializado na assistência às pessoas com DST/AIDS. As modalidades de assistência oferecidas por esse serviço são: Hospital Dia (HD), Atendimento Domiciliar Terapêutico (ADT), Ações de Prevenção por meio de projetos estratégicos, tais como o de "Redução de Danos" para usuário de drogas injetáveis, "Tudo de Bom" para garotas de programa, "Programa de Educação e Prevenção na Sexualidade" para com adolescentes, "Cidadania Arco Íris" para homens que fazem sexo com homens, "Elas por Elas" para mulheres do lar.

O Programa Municipal de DST/AIDS tem o objetivo de desenvolver ações de prevenção e controle da aids e da co-infecção tuberculose/aids. Atualmente, os serviços de saúde com vínculo ao Programa são: 01 centro de Prevenção e Assistência DST/AIDS, 9 Centros de Testagem e Aconselhamento, que realizam o aconselhamento pré e pós-teste e os testes 
sorológicos para DST/HIV, 3 laboratórios de referência, 9 Serviços Ambulatoriais Especializados (SAE) que executam atividades de prevenção, diagnóstico e tratamento, 3 Centros de Referência em DST/AIDS (CR) que possuem maior resolutividade e realizam procedimentos mais complexos e 2 Ambulatórios de Especialidades.

O SAE estudado tem sede própria junto à Secretaria de Saúde do Estado de São Paulo desde 1988. Previamente funcionou por três meses como UBS e Pronto Atendimento 24 horas.

A área de abrangência do SAE agrega quatro subprefeituras e municípios vizinhos, sendo o SAE co-responsável com outros serviços de saúde pela assistência à saúde de uma população de cerca de 1.443 .432 habitantes.

O quadro atual de funcionários no SAE é composto por: 3 clínicos, 4 pediatras, 1 ginecologista, 1 infectologista, 1 fisioterapeuta, 5 psicólogas, 1 educadora de saúde pública, 1 nutricionista, 3 farmacêuticas, 5 enfermeiras, 24 auxiliares de enfermagem, 1 atendente de enfermagem, 3 técnicos de laboratório, 1 agente de apoio, 1 auxiliar de laboratório, 1 técnico de higiene dental, 1 auxiliar cirurgião dentista, 11 escriturários, 12 agentes de apoio readaptados e 1 auxiliar de serviço.

No período de 1996 a 2005, foram matriculados 3.636 pacientes HIVIAIDS nesse SAE, sendo 2.884 adultos (destes, 584 foram a óbito) e 752 crianças (destas 22 foram a óbito). Do total de adultos, 1.238 eram do sexo feminino (destes, 186 foram a óbito). Os dados disponíveis sobre a infecção pelo HIV em crianças se referiam ao período compreendido 
entre 2000 e 2003, durante o qual foram atendidas 248 crianças, com idade entre 15 e zero anos. Do total delas, em 26 ocorreu infecção pelo HIV. interessante observar que as mães de 21 dessas crianças realizaram o prénatal, sendo que somente 4 delas fizeram no SAE DST/AIDS Cidade Líder.

\subsection{Sujeitos de Estudo}

A grupo estudado constituiu-se de mulheres portadoras do HIV que se tornaram mães após o diagnóstico da soropositividade.

A seleção da amostra dos sujeitos do estudo foi feita com base nos seguintes critérios:

- estar matriculada e em acompanhamento no SAE há pelo menos quatro meses;

- ter o diagnóstico de aids (notificada como aids);

- estar em tratamento terapêutico no SAE;

- ter tido pelo menos um filho após o diagnóstico de soropositividade ao HIV;

- o filho, nascido após diagnóstico da soropositividade ao HIV da mãe, deve ter 6 meses de idade, no mínimo, na ocasião da entrevista. Foi estabelecido esse período de vida da criança, por se considerar que seis meses após o nascimento da criança seria o tempo mínimo necessário para adaptação da mulher à condição de mãe. 
- apresentar condições físicas e mentais para participar da entrevista;

Para o desenvolvimento do estudo, foram realizadas entrevistas com 16 mulheres, segundo os critérios estabelecidos. Para preservar a identidade das mulheres, optamos por identificá-las por números.

Ao ser realizado o primeiro contato, na maioria das vezes na espera por consultas com a pediatra, houve duas mulheres que se recusaram a ser entrevistadas. A primeira negou-se a participar do estudo, justificando que não gostaria de relembrar o passado porque a gravidez teve um início muito triste, foi resultado de um ato muita violência, e a segunda não apresentou nenhum motivo.

\subsection{Instrumentos e procedimentos para coleta de dados}

Os dados foram coletados no período de novembro de 2005 a janeiro de 2006.

Foram utilizados dois instrumentos para a coleta de dados: um para a caracterização sócio-demográfica, condições de vida e trabalho e aspectos relacionados ao processo saúde-doença visando conhecer o contexto das mulheres do estudo (Anexo 3). Esses dados foram coletados por meio de consulta ao prontuário clínico e, posteriormente complementados durante a realização da entrevista. O outro instrumento, para a coleta dos dados sobre os significados atribuídos à maternidade e as repercussões de ser mãe no 
controle do processo saúde-doença, consistiu de um roteiro semi-estruturado com questões concernentes à: o que é ser mãe com aids; se a maternidade gera mudanças no cuidado consigo própria; se há diferenças entre ser mãe antes e depois do diagnóstico da aids (para aquelas que tiveram filhos antes do diagnóstico). Esses dados foram coletados por meio de entrevista individual,

Previamente à realização das entrevistas com as mulheres selecionadas para o estudo, entrevistaram-se duas mulheres, que não fizeram parte do estudo, com a finalidade de aprimorar o roteiro semi-estruturado.

Nove entrevistas ocorreram no SAE, enquanto as mulheres aguardavam consultas e, sete em suas residências, após agendamento, conforme suas disponibilidades, com tempo médio de duração de 60 a 90 minutos. Os domicílios localizavam-se na área que abrange a região leste da cidade de São Paulo e uma no município de Guarulhos. Todas as mulheres necessitavam de transporte para se dirigirem ao $\mathrm{SAE}$, percorrendo uma distância de 6 a $20 \mathrm{~km}$. As entrevistas foram realizadas nos meses de setembro a dezembro de 2005.

Em se tratando de um estudo exploratório de natureza qualitativa, a interação entre o pesquisador e os sujeitos pesquisados é fundamental, sendo a entrevista um dos recursos metodológicos mais indicadas para a coleta de dados, por ser uma técnica importante que permite a possibilidade e o desenvolvimento de uma estreita relação entre as pessoas (MINAYO, 2004). Ao término de cada entrevista foram registradas as impressões da pesquisadora sobre o entrevistado, com a finalidade de auxiliar a análise dos dados. 
Conforme esclarece Minayo (2004), a quantidade de respostas só se esgota no momento em que for delineado o quadro empírico da pesquisa, isto é, considera-se suficiente o número que permita a recorrência da mesma informação, porém não se devem descartar comentários adicionais que tenham relevância para o estudo.

Assim, a coleta de dados encerrou-se quando o conteúdo das entrevistas permitiu observar a reincidência das informações, tornando-se repetitivo, não surgindo mais conteúdos novos sobre os aspectos do objeto da pesquisa.

\subsection{Organização dos dados para análise}

Os dados quantitativos foram sistematizados de modo a construir o perfil sócio-demográfico e clínico do grupo estudado.

As entrevistas foram gravadas e, posteriormente, transcritas para os procedimentos de análise. $\mathrm{Na}$ transcrição procurou-se registrar os investimentos afetivos expressos por meio de reticências, das frases interrompidas, das mudanças na tonalidade da voz, dos silêncios, das repetições. Em seguida foram organizadas de forma a permitir a análise do tipo categorial-temática.

A categorização do conteúdo das entrevistas compreendeu a abstração das respostas e comentários apresentados pelas mulheres, após 
várias e atentas leituras do conjunto para que houvesse uma assimilação dos dados por parte da autora.

A análise qualitativa dos dados foi orientada pela análise de conteúdo proposta por Bardin (1979, p.42) que a define como:

[...] um conjunto de técnicas de análise de comunicação visando obter, por procedimentos sistemáticos e objetivos de descrição do conteúdo das mensagens, indicadores (quantitativos ou não) que permitam a inferência de conhecimentos relativos às condições de produção/recepção das mensagens.

Através de leitura e análise, foi reunido um grande número de unidades temáticas e agrupadas por meio do processo de categorização. De acordo com o que preconiza Minayo (2004), a interpretação exige a elaboração de categorias analíticas capazes de desvendar as relações essenciais, mas também de categorias empíricas e operacionais que possam captar as contradições do nível empírico em questão, para uma aproximação do objeto. As unidades temáticas são reagrupadas em torno de categorias centrais, em um processo de aprofundamento da análise.

Dessa maneira, a decomposição dos depoimentos resultou na obtenção de um conjunto de sub-temas, que agrupados constituíram as três categorias empíricas: "a vivência da gravidez (estar grávida tendo aids)", "a expressão da maternidade (ser mãe tendo aids)" e "as implicações da maternidade no cotidiano das mulheres", que sintetizam as percepções das mulheres entrevistadas sobre as implicações da maternidade no seu processo saúde-doença, por meio da análise dos significados atribuídos à gestação, à maternidade e das repercussões no processo saúde-doença vivenciado. 


\subsection{Aspectos éticos}

O projeto de pesquisa foi submetido e aprovado pelo Comitê de Ética e Pesquisa da Secretaria Municipal da Saúde (Anexo 1). O projeto foi também apresentado ao Programa Municipal de DST/AIDS, que autorizou a coleta de dados.

No momento da entrevista todas as mulheres receberam informações sobre a natureza, os objetivos e a metodologia do estudo, além de esclarecimentos sobre a importância de suas contribuições para a realização da pesquisa. Foram também informadas sobre o direito de se retirar do estudo, se assim desejassem, e após assinatura do termo de consentimento autorizado as entrevistas foram realizadas, garantido o sigilo e o anonimato em todos os registros. . 


\section{RESULTADOS E ANÁLISE DOS DADOS}

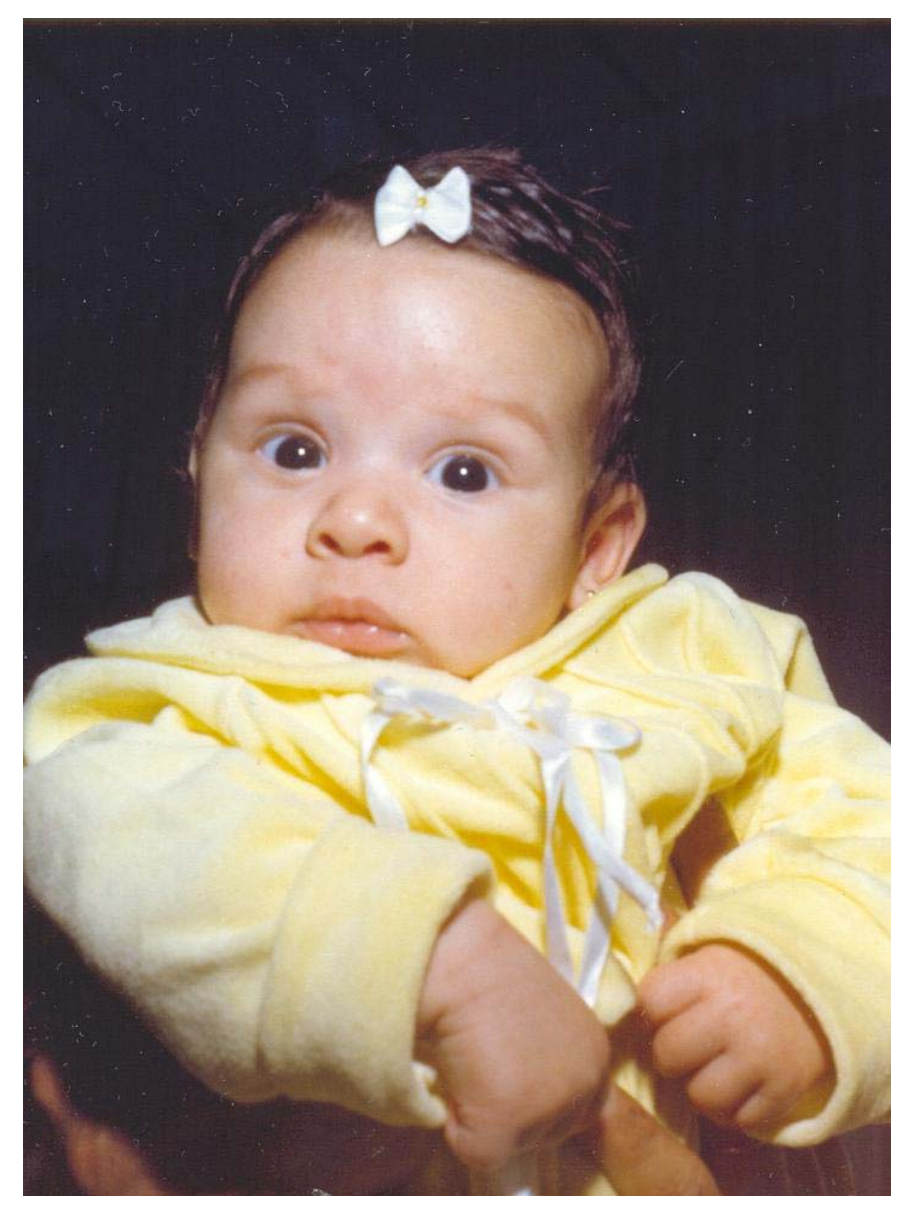

"Nenhum homem é livre se não puder comandar a si mesmo"

(Pitágoras) 


\section{$4 \quad$ RESULTADOS E ANÁLISE DOS DADOS}

\subsection{Conhecendo as mulheres}

\section{RESUMO DA ENTREVISTA}

\section{Entrevista 1}

Idade 29 anos, do lar, está desempregada, anteriormente garota de programa, $1^{\circ}$ grau incompleto, branca, solteira, vive com 4 filhos e companheiro que mora com os pais e freqüenta a casa diariamente, soube da soropositividade há 8 anos no parto do $1^{\circ}$ filho em 1997, tratamento no SAE há 5 anos (resolveu se tratar após 3 anos do diagnóstico), freqüenta a Igreja quadrangular atualmente, possui 4 filhos, sendo $01^{\circ}$ de 8 anos (descobriu no parto), o $2^{\circ}$ de 7 anos e o $3^{\circ} 6$ anos (não fez pré-natal) e $4^{a}$ de 9 meses (fez pré-natal), todos HIV-. Teve 2 companheiros, conviveu 6 anos com o $1^{\circ}$ teve 3 filhos, não sabe sua situação sorológica, o $2^{\circ}$ companheiro tem 18 anos convive há 2 anos, soroconverteu em mai/05, teve 1 filha. Mora em uma casa cedida, recebe doações, não tem renda. Não freqüentou o SAE em 2001, 2002 e 2003, retornou em 10/2004 grávida de 6 meses. Situação atual aids sem ARV. 


\section{Entrevista 2}

Idade 31 anos, faxineira, $1^{\circ}$ grau incompleto, negra, viúva, vive com 3 filhos (o $4^{\circ}$ filho mora com a avó paterna) e o companheiro, soube da soropositividade e iniciou tratamento no SAE há 6 anos, freqüenta há 4 meses Igreja Universal e parou de beber (iniciou a bebida com 12 anos de idade).Teve 4 filhos 15, 14 e 11 anos antes da soropositividade e 1 filho de 2 anos após. Soube da soropositividade em 1999 numa internação para diagnóstico de tuberculose. Teve 4 companheiros, com o primeiro aos 15 anos conviveu 14 anos e teve 2 filhos, o segundo (usuário de drogas e violento) por 2 anos e 2 meses não teve filhos, o terceiro (caminhoneiro, casado) conviveu 3 anos e 6 meses relacionamento esporádico (1996 a 1999) não sabe a situação sorológica, o quarto convive há 2 anos é HIV- . Mora em uma ocupação (comprou de terceiros) 2 cômodos. Renda $\mathrm{R} \$ 1.300,00$ (Incluso benefício). Constantemente internada por pneumonia antes da última gravidez. Mãe faleceu quando tinha 9 anos devido ao alcoolismo do pai, foram adotados. Casou-se aos 14 anos. Situação atual aids com ARV e NICIII

\section{Entrevista 3}

Idade 31 anos, $1^{\circ}$ grau incompleto, vendedora desempregada,branca, solteira, vive com 4 filhos e o segundo companheiro, soube da soropositividade há 12 anos no parto dos primeiros filhos (gêmeos), iniciou tratamento no SAE somente em 2002, o primeiro marido não deixava fazer acompanhamento. Teve 4 filhos: o primeiro e o segundo de 12 anos, o terceiro 5 anos e o quarto de 11 meses, todos HIV- e o quarto exposto. Fez pré-natal e acompanhamento somente do quarto filho.Teve 2 companheiros, 
com o primeiro conviveu 9 anos (HIV+) falecido e o segundo (HIV-) convivem há 2 anos, soube da soropositividade da mulher quando se casaram e incentivou-a a iniciar o tratamento e ter 1 filho. Mora em uma casa alugada ( $R \$ 400,00)$. Renda $R \$ 700,00$. Apresentou NIC ${ }^{*}$ I em 2004. Situação aids com ARV. A soropositividade foi revelada somente à mãe e companheiro.

\section{Entrevista 4}

Idade 34 anos, $2^{\circ}$ grau completo, empregada doméstica, parda, casada, vive com 3 filhos e companheiro. Soube da soropositividade a partir do diagnóstico da segunda filha com 3 meses de idade em 2002 (fez pré-natal em clínica particular com sorologia negativa). Em tratamento no SAE desde 2002. Teve 3 filhos: o primeiro 8 anos e o segundo, 4 anos, antes da soropositividade, e o terceiro, de 1 ano e 3 meses após. A segunda filha é HIV+. Teve 2 companheiros, o primeiro abandonou-a antes do nascimento da segunda filha. O segundo convive há 4 anos é HIV+e teve o terceiro filho hoje HIV- (fez pré-natal no SAE). Mora em uma casa de aluguel. Renda R\$ 1.800,00. Situação atual aids com ARV. Aos 4 anos de idade sua mãe faleceu num parto e seu pai doou os cinco filhos para famílias diferentes, sofreu com a mãe adotiva.

\section{Entrevista 5}

Idade 38 anos, $1^{\circ}$ grau incompleto, passa roupa, desempregada, branca, solteira, vive com 2 filhos. Soube da soropositividade há 6 anos no parto na terceira filha, desde então trata-se no SAE. Teve 4 filhos:

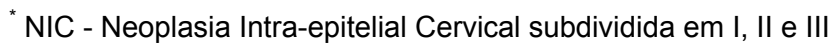


o primeiro, 13 anos, o segundo, 10 anos, antes da sopositividade e moram com a sogra, a terceira, 6 anos(hiv-), não fez pré-natal e o quarto de 9 meses (exposto) realizou pré-natal no SAE. Teve 4 companheiros com primeiro conviveu 8 anos, teve 2 filhos; não sabe da situação sorológica; com o segundo conviveu 3 meses, acredita que tenha se contaminando com ele, com terceiro, conviveu 5 anos teve a terceira filha, ele faleceu assassinado, com o quarto foram apenas 3 encontros, conheceu na sala de espera do SAE, é HIV+ em tratamento. Mora na casa deixada pelos pais que faleceram, não tem renda, vive de doações de vizinhos e uma irmã. Situação atual aids com ARV.

\section{Entrevista 6}

Idade 29 anos, $1^{\circ}$ grau completo, desempregada, recolhe latinhas de refrigerante para vender, branca, solteira, vive com 2 filhos. Teve 2 filhos: o primeiro, 7 anos, quando descobriu sua soropositivade há 7 anos (1997) no pré-natal e em seguida iniciou tratamento no SAE, o segundo tem 1 ano e 4 meses todos HIV- . Tem um companheiro com o qual conviveu 4 anos é HIV+, teve 2 filhos e no momento presidiário. A renda é de seu pai $\mathrm{R} \$ 1.200,00$ que the ajuda. Mora em 1 cômodo da casa de seus pais (os cômodos foram divididos). Situação atual aids com ARV.

\section{Entrevista 7}

Idade 33 anos, $2^{\circ}$ grau incompleto, vendedora autônoma (perfumes), parda, solteira, vive com 2 filhos. Teve 3 filhos, o primeiro, há 9 anos morreu com 1 mês e 15 dias de vida, antes da soropositividade; o segundo, 5 anos e terceiro, 3 anos, após a sua situação sorologica HIV+. Teve 4 companheiros: o primeiro morreu assassinado, o segundo (HIV+) conviveu 4 
anos teve primeiro filho que faleceu, com o terceiro relacionou-se 3 dias e teve o segundo filho, o quarto conviveu 2 anos (separou-se e não contou sobre a sua soropositividade) teve a terceira filha. A renda é de $R \$ 200,00$ mensais. Mora na casa dos pais que já faleceram e ficou dividida entre os irmãos. Apresentou HPV em 2001. Situação atual aids com ARV.

\section{Entrevista 8}

Idade 25 anos, $1^{\circ}$ grau incompleto, negra, recolhe papelão à noite, solteira, não tem religião definida. vive com 3 filhos e o companheiro. Teve 3 filhos a primeira, 5 anos; a segunda, 3 anos (descobriu o HIV em 2003 quando a filha tinha 4 meses em internação), o terceiro, 1 ano e 4 meses, todos HIV-, está grávida. Teve 2 companheiros, o primeiro conviveu 2 anos e não teve filhos, não sabe a situação sorológica e morreu de tuberculose, o segundo companheiro (HIV-) convive há 5 anos, teve os 3 filhos, ele recolhe papelão durante o dia, é alcoólatra, ela recolhe papelão durante a noite. Renda $\mathrm{R} \$ 230,00$ (Sendo $\mathrm{R} \$ 80,00$ de benefício). Mora em um barraco. Situação atual AIDS (trata-se no amb. Hosp.Sta.Marcelina, com ARV). No SAE iniciou pré natal em 2005 e acompanha o tratamento dos filhos há 3 anos. Foi adotada com 1 ano, expulsa da casa da mãe adotiva aos 15 anos.

\section{Entrevista 9}

Idade 28 anos, $1^{\circ}$ grau incompleto, negra, do lar, solteira, vive com 3 filhas e o companheiro. Teve 3 filhas a primeira 6 anos (HIV-) (momento da descoberta da situação sorológica 1999 no pré natal), a segunda com 2 anos (HIV-) e a terceira com 1 mês. Teve 2 companheiros: com o primeiro conviveu 5 anos, já faleceu (HIV+), teve a primeira filha, o segundo 
companheiro HIV-. Paciente acredita que se contaminou com o seu primeiro namorado. Faz tratamento no SAE desde 2000. Renda familiar $\mathrm{R} \$ 600,00$ (Recebe beneficio e salário do companheiro). Mora de aluguel em um cortiço (e cômodos). Nunca abandonou o tratamento. Situação atual aids com ARV.

\section{Entrevista 10}

Idade 33 anos, $1^{\circ}$ grau incompleto, solteira, branca, do lar, vive com 2 filhos. Ficou grávida 7 vezes, 2 óbitos fetais, 2 abortos, 2 filhos, a primeira, 10 anos antes da soropositividade e o segundo, 2 anos HIV-. O diagnóstico há 6 anos (1999) no pré-natal no Hospital Waldomiro de Paula, e em tratamento no SAE também há 6 anos. Teve 3 companheiros: com o primeiro, apenas uma aventura, teve 1 filha; com o segundo companheiro conviveu 5 anos (HIV-) morreu assassinado, teve 1 filho. O terceiro companheiro (violento usuário de drogas) 1 ano e 6 meses, morreu assassinado e está grávida. Mora em uma casa (era um barraco que o segundo companheiro construiu de bloco) com o filho de 2 anos. Recebe auxílio da sogra do segundo companheiro. Situação atual aids com ARV. Saiu de casa para outro estado aos 12 anos.

\section{Entrevista 11}

Idade 23 anos, $2^{\circ}$ grau completo, casada, branca, evangélica, feirante, vive com 1 filha e o marido. Teve 2 filhos, o primeiro morreu logo ao nascer em 2003 descoberta do HIV no pré-natal, iniciou tratamento no SAE em 2002 na gravidez do primeiro filho, a segunda filha nasceu em 2004, está com 1 ano e seis meses HIV-. Teve 2 companheiros, o primeiro conviveu 4 anos não sabe sua situação sorológica e o segundo convive há 2 anos e ocorreu a 
soroconversão este ano. Mora de aluguel em 4 cômodos. Renda familiar $\mathrm{R} \$ 1.000,00$, marido também trabalha. Saiu de casa aos 15 anos. Situação atual aids com ARV.

\section{Entrevista 12}

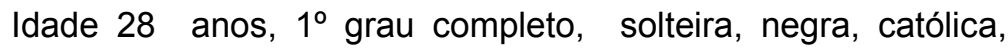
confecciona doces e salgados (autônoma), vive com 3 filhos. Teve 3 filhos o primeiro está com 10 anos (HIV-), o segundo, 5 anos (HIV-), quando descobriu a soropositividade no pré-natal e a terceira com 1 ano e 10 meses (HIV-). Teve 3 companheiros com o primeiro conviveu 5 anos e teve 1 filho, com o segundo (provavelmente HIV-), conviveu 7 meses, teve 1 filho, com o terceiro (provavelmente HIV-) namorou e teve 1 filha (ele não sabe sobre sua soropositividade, é casado). Renda familiar $\mathrm{R} \$ 600,00$. Mora de aluguel R\$180,00. Apresentou NIC* III em 2000. Situação aids com ARV.

\section{Entrevista 13}

Idade 37 anos, $1^{\circ}$ grau completo, solteira, branca, costureira, vive com 7 filhos. Teve 7 filhos; o primeiro com 18 anos, a segunda com 14 anos, a terceira 10 anos. O quarto com 9 anos, a quinta com 4 anos (HIV+) quando descobriu sua soropositividade no pré-natal na UBS com 38 semanas de gestação, o sexto com 3 anos (HIV-) e a sétima com 3 meses (não fez prénatal). Teve 3 companheiros, com o primeiro conviveu 9 anos, teve 4 filhos (provavelmente $\mathrm{HIV+}$ ), usuário de droga injetável, morreu assassinado em 1999, com o segundo companheiro conviveu 3 anos, não sabe da situação

\footnotetext{
* NIC - Neoplasia Intra-epitelial Cervical subdividida em I, II e III
} 
sorológica, o terceiro convive há 4 anos (HIV-), teve 3 filhos, está detento. Mora em uma casa que sua mãe comprou. Não tem renda porque no momento está desempregada, recebe ajuda da mãe e do filho de 18 anos. Situação atual aids sem ARV por abandono nas suas consultas e da filha de 4 anos (HIV+) e da filha de 3 meses, refere que não tem dinheiro para condução e precisa trabalhar para sustento da casa.

\section{Entrevista 14}

Idade 37 anos, $1^{\circ}$ grau incompleto, solteira, empregada doméstica, vive com 3 filhos. Teve 4 filhos, o primeiro tem 13 anos, o segundo morreu aos 3 meses de idade, o terceiro tem 10 anos, é HIV+, a quarta tem 8 anos, é HIV+ (soube da soropositividade em 1999 em internação para diagnóstico de tuberculose) e o quinto tem 3 anos é HIV-. Teve 2 companheiros: com o primeiro conviveu 1 ano, teve 1 filho, com o segundo conviveu 10 anos e teve 4 filhos. Paciente bebia muito e usava droga, o segundo companheiro era violento, separou-se dele e parou de beber e usar droga, começou a trabalhar no início de 2004. Fez laqueadura. Renda familiar $\mathrm{R} \$ 600,00$ (incluso benefício do filho de $\mathrm{R} \$ 300,00$ ). Mora em 1 cômodo, está construindo outro em área de mutirão. Situação atual aids com ARV.

\section{Entrevista 15}

Idade 28 anos, $1^{\circ}$ grau incompleto, solteira, não tem religião definida, já freqüentou a católica, crente e hoje lê livros espíritas, cabeleireira, branca, mora com 3 filhos e o pai. Tem 3 filhos: o primeiro, 12 anos (teve com 16 anos), o segundo, 4 anos HIV- ( descoberta da soropositividade no prénatal) e o terceiro, 1 ano e seis meses, exposto. Teve vários companheiros 
com o pai do primeiro filho, conviveu 2 anos, do segundo filho conviveu 3 anos e do terceiro filho somente saiu com ele. Descobriu a soropositividade no ano de 2000 UBS, no $5^{\circ}$ mês de gravidez do segundo filho e iniciou tratamento no SAE no mesmo ano. Fez laqueadura no último parto. Renda $R \$ 600,00$ (seu salário e pensão dos meninos). Mora em uma casa de 3 cômodos emprestada. Já abandonou o tratamento antes da gravidez. Situação aids com ARV.

\section{Entrevista 16}

Idade 39 anos, $1^{\circ}$ grau incompleto, branca, casada, vendedora de queijos e doces em sua casa, evangélica, vive com 2 filhos e marido. Teve 3 filhos, o primeiro, com 17 anos, a segunda com 7 anos (HIV-), o terceiro com 2 anos (HIV-). Descobriu sua soropositividade em 1993, devido à internação por anemia. Em tratamento no SAE desde 1998 (só iniciou o tratamento quando se casou e engravidou). Teve 2 companheiros: com o primeiro companheiro conviveu 5 anos (tinha 19 anos) HIV- teve 1 filho, o segundo companheiro convive há 8 anos é HIV-. Fez laqueadura no último parto. Renda familiar R\$ 1.600,00. Mora de aluguel em casa com 4 cômodos. Situação atual aids com ARV.

\subsection{Caracterização sócio-demográfica, clínica e das condições de vida das mulheres com aids}

O grupo de estudo foi constituído por 16 mulheres com diagnóstico de aids, matriculadas no SAE DST/AIDS Cidade Líder II há pelo 
menos dois e no máximo sete anos, em acompanhamento clínico-laboratorial por ocasião das entrevistas.

A idade das mulheres variou entre 23 a 39 anos. Nove $(56,2 \%)$ delas pertenciam à faixa etária de 30 a 39 anos, e sete $(43,7 \%)$ tinham entre 23 a 29 anos. A distribuição das mulheres por faixa etária foi semelhante à encontrada em outros estudos (PAIVA, 2000).

No aspecto cor verificou-se uma maior proporção de mulheres brancas, $62,5 \%$ (10), em seguida a cor preta $25 \%$ (4) e parda $12,5 \%$ (2). As relações de gênero e cor determinam uma vida de subsistência ainda mais instável e com menor poder para as mulheres negras/pardas do que para as mulheres brancas da mesma classe. (GUIMARÃES, 2001)

As mulheres possuíam baixo nível de escolaridade: $\quad 68,7 \%$ (11) declararam ter o ensino fundamental incompleto (de 4 a 7 anos de estudo); $12,5 \%$ (2) o ensino fundamental completo; $6,2 \%(1)$ o ensino médio incompleto e $12,5 \%$ (2) o ensino médio completo. Segundo dados do Boletim (2004c), a maioria das mulheres com aids também tiveram um tempo de estudo de 4 a 7 anos, coincidindo com os achados do presente estudo, o que reforça a associação entre baixa escolaridade e incidência da doença.

A influência da escolaridade na apreensão e na capacidade da pessoa em se beneficiar de novos conhecimentos é indiscutível, interfere também no entendimento e conseqüentemente influencia a disseminação do HIV. À luz do conceito da vulnerabilidade, a infecção da mulher pelo HIV é determinada pelo seu acesso ao conhecimento sobre a doença e práticas preventivas à transmissão do vírus. 
Quanto à distribuição das mulheres, segundo o estado conjugal, prevaleceram as solteiras $81,2 \%(13)$, seguidas das casadas $12,5 \%$ (2) e viúvas $6,2 \%$ (1). Metade desse contingente vivia somente com os filhos. Das 13 solteiras, sete $(53,8 \%)$ viviam com o companheiro.

No quesito religião, verificou-se que 43.7\% (7) eram católicas, $31.25 \%$ (5) evangélicas e 25\% (4) declararam não ter nenhuma crença ou religião. As formas de lazer citadas foram: ir à igreja, à praia e freqüentar locais de diversão como bares, realizar passeios, dançar e ler.

No que se refere à empregabilidade, no grupo entrevistado, $56,25 \%$ (9) estavam desempregadas, 25\% (4) possuíam vínculo empregatício com registro em carteira, sendo que duas eram empregadas domésticas, uma feirante balconista, e outra cabeleireira. Do total, 18,7\% (3) eram autônomas, sendo que uma produzia e comercializava produtos alimentícios e as outras duas eram vendedoras.

No que concerne à renda familiar, os ganhos de oito delas variaram de menos de um a três salários mínimos, ao passo que quatro declararam renda familiar de quatro a seis salários mínimos e, outras quatro mães não possuíam qualquer tipo de renda, sendo sustentadas a partir de doações de vizinhos e organizações religiosas. As condições sócio-econômicas dessas mulheres ilustram o fenômeno de pauperização da epidemia.

Quanto à procedência, 68,7\% (11) nasceram na cidade de São Paulo, 25\% (4) em outras cidades do estado de São Paulo, e 6,2\% (1) na Bahia. Em relação ao modo de exposição ao vírus, as 16 mulheres contraíram a doença pela via sexual. 
Como o SAE DST/AIDS Cidade Líder II está localizado na zona leste da cidade de São Paulo, grande parte das entrevistadas, 93,7\% (15), moravam nessa região, exceto uma que se mudou para Guarulhos (Grande São Paulo). Das 16 mulheres do estudo, duas residiam na favela, em condições precárias de habitação, sem rede de esgoto e coleta de lixo. Das 16 mulheres, seis delas informaram viver em casa de aluguel e dez em casa própria (cedidas, ou por herança). Em todos os casos as moradias eram abastecidas com água potável.

Quadro 1 - Distribuição das mulheres entrevistadas quanto à idade, escolaridade, cor, estado civil, ocupação, renda familiar, número de pessoas na família e casa. São Paulo - SP, 2005.

\begin{tabular}{|c|c|c|c|c|c|c|c|c|}
\hline NOME & IDADE & ESCOLARIDADE & COR & $\begin{array}{c}\text { ESTADO } \\
\text { CIVIL }\end{array}$ & OCUPAÇÃO & $\begin{array}{c}\text { RENDA } \\
\text { FAMILIAR }\end{array}$ & $\begin{array}{l}N^{0} \text { PESSOAS } \\
\text { NA FAMILIA }\end{array}$ & CASA \\
\hline E1 & 29 & $1^{\circ}$ incompleto & Branca & Solteira & do lar & nenhuma & 5 & cedida \\
\hline E2 & 31 & $1^{0}$ incompleto & Preta & viuva & diarista & $\mathrm{R} \$ 1.300$ & 6 & própria \\
\hline E3 & 31 & $1^{\circ} \mathrm{g}$.completo & Branca & solteira & do lar & $\mathrm{R} \$ 700$ & 7 & alugada \\
\hline E4 & 34 & $2^{\circ}$ completo & Preta & solteira & empr.dom. & $\mathrm{R} \$ 1800$ & 5 & alugada \\
\hline E5 & 38 & $1^{0}$ incompleto & Branca & solteira & pass.roupa & nenhuma & 3 & herança \\
\hline E6 & 29 & $1^{\circ}$ completo & Branca & solteira & do lar & $\mathrm{R} \$ 1200$ & 8 & cedida \\
\hline E7 & 33 & $2^{\circ}$ completo & Parda & solteira & vendedora & $\mathrm{R} \$ 200$ & 3 & herança \\
\hline E8 & 25 & $1^{\circ}$ incompleto & Parda & solteira & Reciclagem & $\mathrm{R} \$ 230$ & 5 & própria \\
\hline E9 & 25 & $1^{0}$ incompleto & Preta & solteira & do lar & $\mathrm{R} \$ 600$ & 5 & alugada \\
\hline E10 & 33 & $1^{0}$ incompleto & Branca & solteira & do lar & nenhuma & 3 & própria \\
\hline E11 & 23 & $2^{\circ}$ incompleto & Branca & casada & Feirante & $\mathrm{R} \$ 1000$ & 3 & alugada \\
\hline E12 & 28 & $1^{\circ}$ incompleto & Preta & solteira & conf.bolos & $\mathrm{R} \$ 600$ & 4 & alugada \\
\hline E13 & 37 & $1^{\circ}$ completo & Branca & solteira & Costureira & nenhuma & 8 & propria \\
\hline E14 & 37 & $1^{\circ}$ incompleto & Branca & solteira & empr.dom & $\mathrm{R} \$ 600$ & 4 & propria \\
\hline E15 & 39 & $1^{\circ}$ incompleto & Branca & casada & Vendedora & $\mathrm{R} \$ 1500$ & 4 & alugada \\
\hline E16 & 28 & $1^{0}$ incompleto & Branca & solteira & Cabelereira & $\mathrm{R} \$ 600$ & 3 & cedida \\
\hline
\end{tabular}

Em relação ao diagnóstico da soropositividade ao HIV, verificou-se que o tempo de conhecimento da soropositividade oscilou de dois a doze anos, sendo $56 \%$ (9) de seis a doze anos e $44 \%$ (7) de dois a cinco anos. Tiveram dificuldades de informar com precisão as datas, quando houve diferença no tempo de diagnóstico da infecção pelo HIV e da aids. 
Das 16 mulheres, em $18,75 \%$ (3) a procura pelo SAE DST/AIDS ocorreu cerca de 7 a 12 anos, após o diagnóstico da soropositividade, devido ao descrédito seu o do companheiro quanto ao diagnóstico, a procura foi desencadeada pela descoberta. As outras $81,25 \%$ (13) buscaram o SAE imediatamente após a descoberta da soropositividade.

Ressalve-se que as mulheres que tomaram conhecimento da soropositividade ao HIV em hospitais, o diagnóstico foi realizado na década de 1990, período em que o número de serviços especializados em DST/AIDS, no município de São Paulo, era menor que o atual. Verificou-se que o intervalo entre o diagnóstico no hospital e a matricula no SAE era bem maior, de sete a doze anos, nesse sub-grupo de mulheres, do que o intervalo das que receberam o diagnóstico em UBS após o ano 2000, aproximadamente dois meses.

Embora iniciativas tenham sido desenvolvidas para a melhoria da assistência ao pré- natal, alguns problemas permanecem na sistematização, entre eles, a segmentação entre a rede básica e hospitalar. A relação entre as ações de atenção básica à saúde e as ações hospitalares deveria ser de continuidade e complementaridade.

No estudo verificou-se que o fato de as mulheres terem sido comunicadas do diagnóstico de soropositividade ao HIV no hospital, por ocasião do parto, sugere que não realizaram o pré- natal, o que resultou na procura tardia do SAE (7 e 12 anos após o parto).

Apesar de a realização do teste sorológico ao HIV durante o pré-natal estar prevista no Programa de Saúde da Mulher como um 
procedimento de rotina, uma entrevistada relatou que a sorologia ao HIV não foi realizada no pré-natal de gestações anteriores, ocorridas entre 1995 e 1998, sendo que o diagnóstico foi realizado posteriormente durante sua hospitalização e nessa ocasião foi realizado o diagnóstico das duas crianças, então com 4 e 2 anos respectivamente.

Houve casos em que o diagnóstico foi feito nas UBS, mas o encaminhanmento para o SAE foi realizado somente no final da gravidez, resultando na instituição tardia da profilaxia com anti retrovirais, contribuindo para que a criança fosse infectada pelo HIV, e outro caso a mulher não procurou o serviço porque o marido negava a doença e não deixava a mulher se tratar.

Essas situações explicitaram falhas na operacionalização das ações de prevenção da transmissão vertical preconizadas para serem realizadas durante a gestação em UBS.

Por conta de insuficiência como essas dos serviços de saúde e da dificuldade de acesso, as mulheres recebem o diagnóstico de soropositivas ao HIV, na maioria das vezes, no momento do parto ou após, aumentando o risco de exposição da criança.

O Programa de Humanização do Pré-natal estabelece a realização de treinamentos e a adoção de protocolos para o atendimento da gestante soropositiva ao HIV, visando uma abordagem adequada e completa durante o pré-natal, parto e puerpério, tendo como meta a redução dos riscos materno-infantis em níveis muito próximos das gestantes não infectadas. $\mathrm{O}$ Programa também recomenda o desenvolvimento de intervenções com foco na 
dimensão psicossocial da aids, buscando minimizar a discriminação sofrida por estas mulheres. No entanto, as mulheres entrevistadas não referiram terem sido abordadas no que diz respeito à dimensão psicossocial da aids e as suas condições de vida para o enfrentamento do diagnóstico, o que contribuiu para longos períodos de isolamento devido à discriminação e dificuldades de transporte ao SAE, resultando na não adesão ao tratamento prescrito. (BRASIL, 2001b)

Em relação ao local em que foi realizado o diagnóstico da soropositividade ao HIV, verificou-se que $56,2 \%$ (9) mulheres tiveram conhecimento de sua infecção em unidades hospitalares e 43,7\% (7) em Unidades Básicas de Saúde. Em nenhuma delas o diagnóstico da soropositividade foi realizado no SAE.

Quanto ao momento do diagnóstico, somente em $37,5 \%$ (6) mulheres, foi realizado durante a gestação, em 4 (25\%) ocorreu no momento do parto de gestações anteriores. E em outras duas, a soropositividade ao HIV foi constatada, posteriormente ao diagnóstico da infecção em seus filhos, durante internação em instituições hospitalares, Em 3 (18,7\%) ocorreu durante internações hospitalares sendo duas quando foram diagnosticadas com tuberculose e em outra para tratamento de anemia, e em uma mulher $(6,25 \%)$, o diagnóstico deu-se em atendimento de saúde da mulher de rotina na UBS.

Em 10 mulheres (62,5\%), o diagnóstico foi tardio, ocorrendo posteriormente à gestação, confirmando o achado de outros estudos, em que apesar da expansão da aids, muitas mulheres demoram a saber da sua 
doença porque não se sentem vulneráveis ou porque têm dificuldades de acesso aos serviços de saúde não realizam exames ao HIV.

Conforme Souza Junior; Szwarcwald; Barbosa Junior (2004, p.764), grande parte das mulheres não tem acesso ao teste do HIV, seja pela sua condição social, seja por falhas no sistema de saúde. O mesmo autor faz uma reflexão no sentido de que "a ausência de deteç̧ão precoce da infecção pelo HIV durante o pré-natal representa uma oportunidade perdida de intervenção na gestante infectada, limitando as possibilidades de redução da incidência dos casos pediátricos infectados por transmissão materno-infantil".

Oliveira (2004), em seu estudo realizado em UBS's do municipio de São Paulo, que trata da problemática da prevenção de transmissão vertical do HIV no pré-natal, constatou outros aspectos que contribuem com o aumento do risco de exposição ao HIV, tais como: a realização esporádica do aconselhamento pré e pós teste sorológico, a não solicitação de sorologia, a demora da obtenção dos resultados da sorologia bem como dificuldades de comunicação entre usuários e profissionais. Considerou ainda que a assistência no pré-natal segue o modelo biomédico de atenção à saúde, não contemplando os aspectos culturais e sociais da epidemia HIVIAIDS.

Apesar do conhecimento do diagnóstico da soropositividade ao HIV, das 16 mães, duas não fizeram o pré-natal nas gestações posteriores. Os motivos apresentados para justificar esse comportamento foram o descrédito no próprio diagnóstico e a impossibilidade de faltar ao trabalho para não perder o emprego. 
No que tange ao acompanhamento clínico dessas mulheres, para maior entendimento, fazem-se necessários alguns esclarecimentos sobre os conceitos de adesão ao tratamento, falência medicamentosa e abandono.

Teixeira; Paiva; Shimma (2000) propõem como parâmetros de definição de aderência ao tratamento terapêutico com anti-retrovirais a ingestão mínima de $80 \%$ do total de comprimidos prescritos.

No SAE, os profissionais consideram abandono de tratamento quando a carga viral está acima de 5000 cópias por ml. A adesão ao tratamento, é definida pela ingestão de $90 \%$ dos anti-retrovirais prescritos, por uma contagem de linfócitos (CD4) maior que 350 células $/ \mathrm{mm}^{3}$ e pela carga viral indetectável.

Sete $(43,7 \%)$ mulheres deste estudo mantinham adesão ao tratamento tanto antes, como durante e após a gestação; outras seis apresentaram adesão a partir do momento em que souberam da gravidez e uma $(6,25 \%)$ no decorrer da gestação. Uma $(6,25 \%)$ passou a ter tratamento regularmente após o nascimento do filho (parou de beber, separou-se do marido, começou a trabalhar) e uma $(6,25 \%)$ manteve tratamento irregular, mesmo após a gestação, (faltando às consultas devido ao trabalho ou procura do mesmo e dificuldades financeiras para transporte, sozinha, companheiro detento, 7 filhos), mesmo tendo sido orientada sobre os riscos da TV do HIV, conforme consta nos registros do prontuário clínico. Assinala-se que ao longo do período de aproximadamente 7 anos, houve intervalos de ausência no SAE, ocorridos antes das últimas gestações, que ocasionaram interrupção no tratamento e falência medicamentosa. 
Quadro 2 - Distribuição de mulheres segundo local e tempo de diagnóstico, tempo de matrícula e adesão ao tratamento. São Paulo - SP, 2005.

\begin{tabular}{|ccccccc|}
\hline \multirow{2}{*}{ Nome Diagnóstico } & \multicolumn{2}{c}{ Tempo matrícula } & \multicolumn{3}{c|}{ Adesão ao tratamento } \\
& Local & Tempo & no SAE & Pré Gestação & Gestação & Pós Gestação \\
\hline 1 & Hospital & 8 anos & 5 anos & não & após $6^{\circ}$ mês & sim \\
2 & Hospital & 6 anos & 6 anos & não & sim & sim \\
3 & Hospital & 12 anos & 3 anos & não & sim & sim \\
4 & Hospital & 3 anos & 3 anos & sim & sim & sim \\
5 & Hospital & 6 anos & 6 anos & sim & sim & sim \\
6 & Hospital & 7 anos & 7 anos & sim & sim & sim \\
7 & Unidade Básica de saúde & 7 anos & 7 anos & sim & sim & sim \\
8 & Hospital & 2 anos & 1 ano & sim & sim & sim \\
9 & Unidade Básica de Saúde & 6 anos & 5 anos & sim & sim & sim \\
10 & Hospital & 6 anos & 6 anos & não & sim & sim \\
11 & Unidade Básica de Saude & 3 anos & 3 anos & não & sim & sim \\
12 & Unidade Básica de Saúde & 5 anos & 5 anos & sim & sim & sim \\
13 & Unidade Básica de Saúde & 4 anos & 4 anos & sim & não & não \\
14 & Hospital & 6 anos & 6 anos & não & não & sim \\
15 & Unidade Básica de Saúde & 4 anos & 4 anos & não & sim & sim \\
16 & Hospital & 12 anos & 7 anos & não & sim & sim \\
\hline
\end{tabular}

Sande et al (2005) afirmam que a sobrevivência está relacionada ao acesso ao cuidado, que nas mulheres pertencentes a grupos sociais mais desprivilegiados é menor. O grau de acesso dessas mulheres é decorrente dos hábitos relacionados à saúde transmitidos pelas famílias aos seus descendentes, em que os cuidados com a saúde que se caracterizam por ser muito mais curativos do que preventivos e em que a procura de equipamentos de saúde tende a ocorrer apenas no evento doença.

No que se refere ao uso de métodos anticonceptivos, no momento da entrevista, verificou-se que das 16 mulheres, 31,5\% (5) fizeram laqueadura após o nascimento do filho, $25 \%$ (4) referiram continuar com o uso de preservativo, apesar de a gravidez ter ocorrido devido a acidente durante sua utilização, $18,7 \%$ (3) relataram dificuldades para negociar o uso do preservativo, $18,7 \%$ (3) mencionaram ter planos para fazer laqueadura e $6,2 \%$ (1) afirmou usar anticoncepcional injetável. 
A análise revelou que em onze mulheres persiste a possibilidade de ocorrer uma nova gravidez. A maioria das mulheres $68,7 \%$ (11) referiu não ter participado nenhuma vez de grupos de planejamento familiar. Em relação ao processo reprodutivo, as práticas adotadas após o nascimento dos filhos - associadas à não participação em grupos sobre o planejamento familiar - demonstram a necessidade premente de se incrementar as ações concernentes à gravidez, desejada ou não, que sejam capazes de dar acesso a discussões e aos meios preventivos e minimizar a vulnerabilidade do feto à infecção pelo HIV e a vulnerabilidade da mãe ao adoecimento.

O debate e a proposição de medidas acerca de contracepção em mulheres com HIV devem levar em conta as implicações do uso dos diferentes métodos contraceptivos na evolução da aids. Segundo Sande et al (2005), $85 \%$ das mulheres com aids estão em idade fértil e certos contraceptivos podem representar risco para a sua saúde: a esterelização não protege contra o HIV, havendo o risco de reinfecções se não estiver associada ao uso de preservativos masculino ou feminino. O contraceptivo oral pode aumentar a progressão da doença, pois são comuns interações medicamentosas que alteram o mecanismo de absorção das drogas. O DIU (dispositivo intra-uterino) pode ampliar o risco de (DIP) doença inflamatória pélvica; e a adoção do diafragma cervical ou de esponja pode provocar abrasões vaginais que potencializam o surgimento de infecções. O emprego do espermicidas-gel, como o nonoxinol-9, pode acentuar o risco de transmissão do HIV. 
Analisando-se os prontuários clínicos, constatou-se que das 16 mulheres estudadas, $4(25 \%)$ apresentaram outros agravos, como problemas ginecológicos, sendo duas com (E2 e E12) NIC* III, uma com NIC I (E3) e outra com (E7) HPV.

A simultaneidade de ocorrências dessas outras enfermidades com a aids, requer cuidados adicionais como a realização freqüente de exames de citologia oncótica, também pelo fato de as mulheres estarem mais sujeitas ao acometimento de outras infecções e com maior chance de evolução do agravo para câncer. (Sande et al, 2005)

No que concerne à situação conjugal, as mulheres referiram ter convívido com até quatro parceiros, sucessivamente. A duração do tempo de relacionamento com esses companheiros variou de 1 dia a 14 anos. $\mathrm{Na}$ ocasião da entrevista, 8 mulheres relataram estar convivendo com seus companheiros, 6 viviam apenas com os filhos e os companheiros de duas mulheres eram presidiários.

A situação de infecção ao HIV dos companheiros atuais era de: 6 eram soronegativos ao HIV (sorodiscordantes), 4 eram soropositivos ao HIV, dos quais, dois foram infectados em contatos com as mulheres do estudo. Nos outros 6 , era desconhecida a situação sorológica ao vírus, porque foram contatos esporádicos, sem continuidade no relacionamento.

Todas as mulheres já eram mães antes do diagnóstico de aids, sendo que $56,2 \%$ (9) tiveram apenas um filho no período que antecedeu a

\footnotetext{
* NIC - Neoplasia Intra-epitelial Cervical subdividida em I, II e III
} 
descoberta da soropositividade ao HIV. O número total de filhos, incluindo o período pré e pós-diagnóstico, variou de dois a quatro. 
Quadro 3 - Distribuição das mulheres segundo idade, número de filhos pré e pós diagnóstico de aids, situação atual, idade e diagnóstico dos filhos. São Paulo-SP, 2005.

\begin{tabular}{|c|c|c|c|c|c|c|c|c|}
\hline \multirow[b]{2}{*}{ MULHER } & \multirow[b]{2}{*}{ IDADE } & \multicolumn{2}{|c|}{$\mathrm{N}^{\circ} \mathrm{DE}$ FILHOS } & \multirow{2}{*}{$\begin{array}{l}\text { Situação } \\
\text { Atual }\end{array}$} & \multirow{2}{*}{$\begin{array}{l}\text { Idade } \\
\text { Atual }\end{array}$} & \multicolumn{3}{|c|}{ Diagnóstico dos filhos } \\
\hline & & $\begin{array}{c}\text { Pré } \\
\text { Diagnóstico }\end{array}$ & $\begin{array}{c}\text { Pós } \\
\text { Diagnóstico }\end{array}$ & & & Exposto & Positivo & Negativo \\
\hline \multirow[t]{4}{*}{ E1 } & \multirow[t]{4}{*}{29} & 1 & & vivo & $8 a$ & & & $\operatorname{sim}$ \\
\hline & & & 1 & vivo & $7 a$ & & & $\operatorname{sim}$ \\
\hline & & & 1 & vivo & $6 a$ & & & $\operatorname{sim}$ \\
\hline & & & 1 & vivo & $9 \mathrm{~m}$ & Sim & & \\
\hline \multirow[t]{4}{*}{ E2 } & \multirow[t]{4}{*}{31} & 1 & & vivo & $15 a$ & & & $\operatorname{sim}$ \\
\hline & & 1 & & vivo & $14 a$ & & & $\operatorname{sim}$ \\
\hline & & 1 & & vivo & $11 a$ & & & $\operatorname{sim}$ \\
\hline & & & 1 & vivo & $2 a$ & & & sim \\
\hline \multirow[t]{4}{*}{ E3 } & \multirow[t]{4}{*}{31} & 1 & & vivo & $12 a$ & & & $\operatorname{sim}$ \\
\hline & & 1 & & vivo & $12 a$ & & & $\operatorname{sim}$ \\
\hline & & & 1 & vivo & $5 a$ & & & $\operatorname{sim}$ \\
\hline & & & 1 & vivo & $11 \mathrm{~m}$ & Sim & & \\
\hline \multirow[t]{3}{*}{ E4 } & \multirow[t]{3}{*}{34} & 1 & & vivo & $8 a$ & & & $\operatorname{sim}$ \\
\hline & & 1 & & vivo & $4 a$ & & $\operatorname{sim}$ & \\
\hline & & & 1 & vivo & $1 a$ & & & $\operatorname{sim}$ \\
\hline \multirow[t]{4}{*}{ E5 } & 38 & 1 & & vivo & $13 a$ & & & $\operatorname{sim}$ \\
\hline & & 1 & & vivo & $10 a$ & & & $\operatorname{sim}$ \\
\hline & & & 1 & vivo & $6 a$ & & & $\operatorname{sim}$ \\
\hline & & & 1 & vivo & $9 m$ & Sim & & \\
\hline E6 & 29 & 1 & & vivo & $7 a$ & & & sim \\
\hline & & & 1 & vivo & $1 a$ & & & $\operatorname{sim}$ \\
\hline E7 & 33 & 1 & & morto & $9 a$ & - & - & - \\
\hline & & & 1 & vivo & $5 a$ & & & sim \\
\hline & & & 1 & vivo & $3 a$ & & & $\operatorname{sim}$ \\
\hline E8 & 25 & 1 & & vivo & $5 a$ & & & $\operatorname{sim}$ \\
\hline & & 1 & & vivo & $3 a$ & & & $\operatorname{sim}$ \\
\hline & & & 1 & vivo & $1 a$ & & & sim \\
\hline & & & gravida & & & & & \\
\hline E9 & 25 & 1 & & vivo & $6 a$ & & & sim \\
\hline & & & 1 & vivo & $2 a$ & & & $\operatorname{sim}$ \\
\hline & & & 1 & vivo & $1 \mathrm{~m}$ & Sim & & \\
\hline E10 & 33 & 1 & & vivo & $10 a$ & & & $\operatorname{sim}$ \\
\hline & & & 1 & vivo & $2 a$ & & & sim \\
\hline & & & gravida & & & & & \\
\hline E11 & 23 & 1 & & natimorto & $2 a$ & - & - & - \\
\hline & & & 1 & vivo & 1a $6 \mathrm{~m}$ & & & $\operatorname{sim}$ \\
\hline E12 & 28 & 1 & & vivo & $10 a$ & & & sim \\
\hline & & 1 & & vivo & $5 a$ & & & sim \\
\hline & & & 1 & vivo & 1a 10m & & & $\operatorname{sim}$ \\
\hline E13 & 37 & 1 & & vivo & $18 a$ & & & sim \\
\hline & & 1 & & vivo & $14 a$ & & & sim \\
\hline & & 1 & & vivo & $10 a$ & & & sim \\
\hline & & 1 & & vivo & $9 a$ & & & $\operatorname{sim}$ \\
\hline & & 1 & & vivo & $4 a$ & & sim & \\
\hline & & & 1 & vivo & $3 a$ & & & sim \\
\hline & & & 1 & vivo & $3 m$ & Sim & & \\
\hline E14 & 37 & 1 & & vivo & $13 a$ & & & sim \\
\hline & & 1 & & morto & & - & - & - \\
\hline & & 1 & & vivo & $10 a$ & & sim & \\
\hline & & 1 & & vivo & $8 a$ & & sim & \\
\hline & & & 1 & vivo & $3 a$ & & & $\operatorname{sim}$ \\
\hline E15 & 28 & 1 & & vivo & $12 a$ & & & sim \\
\hline & & & 1 & vivo & $4 a$ & & & sim \\
\hline & & & 1 & vivo & 1a e $6 \mathrm{~m}$ & & & sim \\
\hline E16 & 39 & 1 & & vivo & $17 a$ & & & sim \\
\hline & & & 1 & vivo & $7 a$ & & & sim \\
\hline & & & 1 & vivo & $2 a$ & & & sim \\
\hline
\end{tabular}


Em síntese as características do perfil sócio-demográfico do grupo de estudo são: jovens, em situação de pauperização, pouco escolarizadas, com relações conjugais de curta duração, cercadas por violência e drogas. Quanto à caracterização do processo saúde-doença do grupo, as mulheres foram infectadas por via sexual e só souberam disso mais tarde quando engravidaram ou em internações hospitalares. Vê-se aí uma estreita relação entre as precárias condições de vida, a forma como as mulheres foram infectadas pelo HIV e o acontecimento da gravidez, condicionando-as à maior vulnerabilidade ao adoecimento e morte pelo HIV e a ocorrência da transmissão vertical do HIV.

No quadro 3 , pode-se verificar que as $4(13,3 \%)$ crianças em que se deu a transmissão vertical são frutos de gestações ocorridas previamente ao diagnóstico de aids das mães (E4, E13, E14).

A E4 submeteu-se à sorologia durante o pré-natal com resultado negativo em clínica particular; só soube do diagnóstico 3 meses após o nascimento na internação de sua filha.

A E13 iniciou o pré-natal na UBS, aos 5 meses de gestação, e no $7^{\circ}$ mês da gestação soube da soropositividade ao HIV. Em seguida foi encaminhada ao SAE, quando iniciou a profilaxia, com antiretrovirais.

A E14 nas 2 gestações anteriores ao diagnóstico do HIV fez pré-natal; não sabe se a sorologia ao HIV foi realizada, só soube da infecção em uma internação para o diagnóstico de tuberculose. 


\subsection{Conhecendo os significados de ser mãe}

Do trabalho de construção de dados, a partir da transcrição das entrevistas e de diversas leituras flutuantes das falas, foram extraídas três categorias: "a vivência da gravidez" (estar grávida tendo aids) e "a expressão da maternidade" (ser mãe tendo aids), e "as implicações da maternidade no cotidiano", que sintetizam as percepções das mulheres entrevistadas sobre as implicações da maternidade no seu processo saúde-doença, por meio da análise dos significados atribuídos à gestação, à maternidade e suas repercussões no processo saúde-doença vivenciado.

A categoria "a vivência da gravidez" abrange os determinantes da gravidez, os sentimentos experimentados nesse período e as repercussões da gestação no cotidiano dessas mulheres.

A categoria "a expressão da maternidade" compreende as seguintes sub-categorias: significados atribuídos à maternidade, dificuldades enfrentadas após o nascimento da criança e repercussões de ser mãe.

A categoria "as implicações da maternidade no cotidiano" das mulheres agrega as repercussões da maternidade no enfrentamento do processo saúde-doença e em sua vida, incluindo as relações familiares e sociais. 


\subsubsection{A vivência da gravidez}

Os motivos que determinaram a ocorrência da gravidez nessas mulheres abrangem três dimensões interdependentes: do sentir, do pensar e do agir. No âmbito do sentir foram identificados vários desejos, cuja origem incide sobre as necessidades afetivas e valores culturais desse grupo, como os motivos que levaram essas mulheres a engravidar. Acresceu-se a esses desejos as crenças e conhecimentos acerca do processo saúde-doença em curso que, conjuntamente, nortearam seus comportamentos, culminando na ocorrência da gravidez, caracterizando o pensar e o agir das mulheres estudadas.

Um dos determinantes da gravidez no grupo de estudo foi o desejo de ser mãe, para realizar um sonho que foi cultivado desde a infância, ao experimentar os diversos papéis da mulher na família, com as brincadeiras de "boneca". Havia também o sonho de constituir família que traz a possibilidade de consolidação e fortalecimento dos vínculos afetivos e do crescimento pessoal. Acrescentou-se a isso a expectativa da sociedade de que toda mulher tenha filhos, numa visão idealizada do papel de mãe.

\footnotetext{
"Era um sonho ser mãe mesmo tendo medo, não pelo HIV, medo natural, medo da dor do parto". E7
}

Nos discursos dos sujeitos da pesquisa, emergiu sutilmente o valor atribuído à maternidade, a qual é considerada uma condição que traz a possibilidade de realização plena enquanto mulher, a tal ponto que o desejo de 
ser mãe sobrepõe-se aos medos da transmissão do HIV e das conseqüências de serem portadoras da aids. Os sentimentos de culpa, pela possibilidade de elas serem meios de transmissão da doença, de sofrimento pelas limitações que o agravo provoca, ficam sublimados pela perspectiva de ser mãe, conforme se pode ler nas falas abaixo transcritas:

“Uma dádiva, ser mãe é tudo. Um dom que não tem explicação. É uma coisa trabalhosa, muita responsabilidade, mas é o que tem de mais importante no mundo, na vida, é a lei da vida ser mãe" E3

A gravidez foi também resultante do desejo de querer amar e ser amada, aliado ao desejo de satisfazer as expectativas do companheiro em ser pai. Essa aspiração masculina está associada à necessidade humana. Outro fator determinante no homem para ser pai é o anseio de comprovar sua virilidade, correspondendo às expectativas da sociedade. (SALDANHA, FIGUEIREDO, 2002)

“... quando você gosta daquela pessoa, tem desejo de ter um filho dele... há 12 anos eu conheço ele e gosto muito dele." E7

Em alguns relatos verificou-se que, face ao desejo do companheiro de ter filhos, a mulher engravida como uma forma de retribuir-lhe a aceitação do seu diagnóstico, em sendo ele sorodiscordante.

Assim, havia mulheres que em segundas ou terceiras uniões, a despeito de já terem filhos, soropositivos ou não, optaram por aumentar a prole, mesmo tendo conhecimento da possibilidade de transmitir o vírus ao parceiro e/ou ao feto, como se pode verificar no depoimento abaixo: 
“... eu queria porque com ele, eu estava começando uma vida ... foi mais para satisfazer um desejo dele. Ele não é positivo e mesmo sabendo da minha doença, ele sempre quis. Até hoje, eu falo que ele tem que se proteger" E13

Os significados atribuídos à gravidez estão relacionados com a realização de um desejo que possibilita a essas mães resgatarem sua identidade como mulher na sociedade.

“... gerar uma criança sadia... "E1

Ademais, enfrentar o desafio de ser mãe na condição de portadora do HIVIAIDS pode representar um anúncio à sociedade de que é "normal!", pois é capaz de cumprir o papel de mulher na sociedade.

A esse propósito vale lembrar as palavras de Ruggiero (2000, p. 8):

A gravidez é um período caracterizado não unicamente por um processo biológico natural, mas é uma representação ideológica que proporciona uma imagem total da mulher-mãe, cuja incorporação faz com que a deseje, para que possa exercer a sua real função na sociedade.

Ainda de acordo com essa mesma autora, poder gerar um filho representa para a mulher com aids uma condição de normalidade, o que the confere um valor que a doença the roubou.

Para Knauth (1999), manter a atividade reprodutiva é uma forma de enfrentar os danos sociais, culturais e mesmo psicológicos decorrentes da aids. 
Os resultados do presente estudo corroboram a constatação de Santos et al (2002) em seu estudo com mulheres portadoras do HIV, de que a aids não modifica a intenção da mulher em se tornar mãe.

Relatos também evidenciam a gravidez como desejo de Deus, como é o caso em que a mulher, grávida do $5^{\circ}$ filho, atribuiu o evento gravidez à vontade de Deus.

"Eu tinha vontade de ter um filho, aí aconteceu. Deus quis que eu tivesse mais." E8

As crenças e conhecimentos acerca da aids constituíram as manifestações que se circunscrevem na esfera do pensar, sendo de ordem cognitiva, pois se referem à informação, à consciência do problema e às formas de enfrentá-lo, o que, conforme Ayres et al. (1999), afeta a vulnerabilidade individual à infecção e ao adoecimento pelo HIV.

Apesar do tempo de diagnóstico, o conhecimento sobre a doença era incorreto "só tenho o vírus", ou seja, não fazem distinção entre os estados de infecção e doença, pois todas as mulheres que já tinham sido notificadas como portadoras de aids tomavam antiretrovirais, mas por apresentarem raramente sinais e sintomas, não se reconheciam portadoras da doença. A ausência de sintomatologia associada a uma gestação sem intercorrências, na concepção dessas mulheres, é interpretada como inexistência da doença, reforçando a representação de que a pessoa é doente somente quando há manifestação de sinais e sintomas ou há incapacidade para o trabalho. No entanto, grande parte dos exames laboratoriais feitos antes 
ou durante a gravidez evidenciou alterações que comprovavam o estado de doença.

Segundo Berlinguer (1988, p.44), existem quatro dimensões do fenômeno "Estar e poder estar doente": estar doente - ter alterações por causa de doença no corpo e suas funções; sentir-se doente - perceber tais modificações no próprio organismo; identificar a doença, com base nos conhecimentos adquiridos na época e conhecidos do indivíduo e poder estar doente, o que depende tanto do tipo de doença quanto do tipo de trabalho (pode ser indiferente para um e impedir as atividades para outro). O mesmo autor acrescenta que o sentir-se doente está relacionado à percepção do próprio corpo. Nos indivíduos de classes menos favorecidas é freqüentemente escassa a cultura somática, enquanto nas classes mais altas existe maior costume de observar os sinais que vêm do próprio corpo.

Em um relato, por exemplo, uma respondente revela não ter claro o conceito de infecção por HIV. Ela julga-se à sombra do adoecimento, considera-se "apenas" infectada, ou seja, a doença está em estado latente, sendo que já foi realizado o diagnóstico da aids.

"Eu não sou doente, só tenho vírus. Estou bem, não sinto nada." E1

"Prá mim não tem doença, não me sinto doente, eu me sinto uma pessoa normal; faço tudo o que uma pessoa normal deve fazer, o único problema é ter de tomar remédio direto" E9

Neves (2005, p.76) comenta em seu estudo que "os profissionais de saúde devem manter uma 'escuta ativa' frente às mulheres 
soropositivas para identificar se o fato de subestimar o HIV é uma atitude positiva, como uma forma de sobrevivência de alguém que conhece a severidade da doença, ou negativa, devido à descrença naquilo que não é concreto e, portanto, não deve ser severo."

A maior parte das entrevistadas reconhecia-se apenas como portadoras do vírus e que a tomada da medicação era decorrente do nível baixo de CD4 e da taxa elevada da carga viral, sem associar esses dois parâmetros à manifestação da doença. Tal condição alimentou a esperança de não transmitir o vírus.

Nas entrevistas e nos prontuários clínicos das mulheres sujeitos de nossa pesquisa, observaram-se registros e relatos de poucos eventos de doenças oportunistas ou internações durante o acompanhamento no SAE. No entanto, encontrou-se com freqüência dados que indicavam falências de tratamento e alterações na avaliação de CD4 e da carga viral.

Deve-se levar em conta também que, muitas vezes, a equipe médica responsável pela assistência no pré-natal apenas comunica resultados, não esclarecendo em linguagem acessível os significados dos exames, bem como da doença em si. Isso contribui para que se reproduzam as falas dos profissionais, sem a compreensão adequada da sua situação clínica, além de impedir o dimensionamento das implicações dessa condição na evolução da doença.

Refletindo-se sobre as causas das distorções do conhecimento e das crenças equivocadas por parte das mulheres, é válido lembrar que o grupo de mulheres tinha baixa escolaridade, o que pode contribuir para a 
existência de dificuldades na compreensão adequada do seu processo saúdedoença e no menor acesso às informações.

Segundo Helmann (1994, p.114), na maioria das culturas, as teorias leigas fazem parte de um complexo de heranças populares, influenciadas por conceitos veiculados pelos meios de comunicação e emanados do modelo médico.

O descrédito sobre estar com o HIV, mas não transmiti-lo devido à ausência de sintomas, contribui com o descaso para com o tratamento.

Neves (2005, p.75) afirma que:

[...] a inexistência de sintomas concretos tais como dor, febre e outras alterações perceptíveis, pode resultar em uma descrença com relação à existência do HIV, estimulando um comportamento inapropriado à saúde e não considerando a severidade da doença.

Os conhecimentos baseados no senso comum, "a sabedoria popular", interferem nas atitudes das pessoas frente à doença e respectivo tratamento. A esse respeito, são oportunas as afirmações de Helman (1994, p.114):

[...] as teorias leigas sobre a causalidade das doenças fundamentam-se em premissas cientificamente incorretas, os modelos leigos normalmente possuem consistência e lógica internas, o que ajuda a vítima a encontrar sentido e motivo para o que lhe aconteceu.

Segundo o mesmo autor, entre as causas das doenças na visão dos leigos, está a vulnerabilidade pessoal, que engloba a vulnerabilidade física, baseada em conceitos de resistência e fraqueza do organismo. 
"Não esperava engravidar, já estava fraca ...,pensei que não iria ter filho mais." E5

A gravidez pode também ser decorrente do descrédito na existência da doença devido a crenças religiosas, em que adotam uma atitude de negação da doença, atribuindo a sua causa, ou melhor, sua origem a "coisas do mal".

"Eu não acredito nessa doença, sei que ela existe, mas não acredito; acho que é coisa do mal." E2

Ademais, verifica-se no decorrer de alguns relatos das mulheres, que a religião fornece suporte para alterar sua condição de portadora de um mal, que poderia ser erradicado pela fé. A crença na cura da enfermidade, por meio da fé religiosa, a deixa sem culpa para satisfazer seu desejo de ser mãe.

"A gente tem uma fé em Deus", eu acho que vai da fé da pessoa, porque tem gente ... que não tem aquela fé que Deus pode curar." E16

Outro fator que predispõe a mulher com aids a conceber é a credibilidade na eficácia dos medicamentos antiretrovirais para impedir a transmissão vertical. Verificou-se que até mesmo as mulheres com filhos soropositivos ao HIV, engravidaram novamente, face ao fato de terem, também, filhos soronegativos.

"Você tem de tomar mesmo, não falhar. Se, esquecer de tomar num dia, toma no outro. A mulher que está grávida tem de tomar todo santo dia." E7

Barbosa e Knauth (2003), em estudo realizado no Brasil, consideraram que o desejo de uma mulher portadora do HIV ter filhos pode 
estar baseado na queda significativa no risco de transmissão materno-infantil, proporcionada pelo uso dos anti-retrovirais.

Consoante Knauth (1999), as mulheres preferem acreditar que suas crianças não terão aids. O que vem reforçar essa crença são fatores tais como: o pai da criança não está doente e contatos com outras mulheres, cujos filhos vieram a negativar nos primeiros meses de vida.

Assim, a convivência no SAE com outras mães com aids, cujos filhos são soronegativos ao HIV, reforça a credibilidade no tratamento e estimula o desejo de ter filhos. Nos últimos seis anos, nesse serviço de saúde, de 443 crianças acompanhadas mensalmente até dois anos de idade, 31 (6\%) tornaram-se soropositivas.

Outro determinante da ocorrência da gravidez situa-se no âmbito comportamental, uma vez que parte das mulheres não tinha o desejo de engravidar. A análise dos seus comportamentos e dos seus parceiros revelou que a gravidez foi decorrente do uso irregular ou inadequado do preservativo, ou da não adoção dessa prática de prevenção. Tais comportamentos estão vinculados a preconceitos relativos ao uso da camisinha, à omissão do diagnóstico, à credibilidade na existência da doença e a sentimentos de "viver o presente".

Ayres et al. (1999) esclarece que a vulnerabilidade individual ao adoecimento, em portadores de HIVIAIDS, pode ser afetada por condições comportamentais: interesse e habilidade para transformar atitudes e ações a partir de elementos cognitivos. 
Houve um caso em que o companheiro não aceitava o uso do preservativo, embora o casal fosse sorodiscordante, pois considerava essa prática uma atitude ofensiva a ela.

\begin{abstract}
"Ele achava que se usasse o preservativo comigo estaria tendo preconceito; e nisso dele achar que estava me diminuindo, estava me tratando como uma mulher desconhecida ... Eu sempre falava pra ele: a gente tem que usar o preservativo para que você não seja contaminado ... Ás vezes ele usava. Então neste "de vez em quando" (usar camisinha) eu fiquei grávida." E 11
\end{abstract}

O relato mostra também uma contradição entre o discurso (o falar) e o comportamento (o agir) da mulher, pois sendo portadora de aids, embora demonstrando ter conhecimento da possibilidade de transmissão do vírus, consentia em ter relações sexuais sem proteção.

A vulnerabilidade à infecção ao HIV é determinada pelo conhecimento acerca da aids e a capacidade efetiva de transformá-lo em comportamentos que configurem proteção à transmissão do vírus. É oportuno acrescentar que o comportamento do casal tornou o parceiro vulnerável, resultando na sua infecção, conforme informou a entrevistada.

O uso esporádico de preservativo no relacionamento do casal pode indicar que houve um pacto silencioso: "o fazer de conta que estão se prevenindo". Com relação a isso, encontra-se respaldo em Neves (2005), segundo o qual, o convívio com o ser amado e a confiança nele depositada propiciam a negação do risco. Embora as mulheres tenham informações corretas a respeito, não usam preservativo em relações estáveis em função da desigualdade de gênero, dada a dificuldade de negociação do seu uso. 
Para algumas mulheres, não exigir o uso da camisinha nas relações sexuais relaciona-se à busca e à dificuldade de ter um companheiro face à convivência com uma doença incurável e extremamente estigmatizante. Essa condição impulsiona-as a adotarem comportamentos que aumentam sua vulnerabilidade ao adoecimento e morte pela aids e expõe seus companheiros ao HIV. Isso ocorre especialmente em relacionamentos de curta duração ou esporádicos, em que as mulheres buscam viver o momento, desconsiderando as conseqüências de seus comportamentos.

\footnotetext{
"Meu segundo filho, que é do segundo companheiro, eu planejei, vivia com ele há mais de três anos e quando engravidei e contei que tinha aids ... ele foi embora. A menina foi um escorregão..., engravidei após um único encontro. "E15
}

Outro fator para o não uso do preservativo é a descrença na existência da doença por parte do homem, como sugerem as palavras de uma das entrevistadas:

"Ele falou: o que tiver que ser vai ser. Eu quero um filho seu e a gente não vai usar preservativo." E3

Observou-se ainda, em algumas situações, que a não utilização ou uso irregular do método contraceptivo decorre do desconhecimento dos parceiros sobre o diagnóstico da aids na mulher, o que os torna vulneráveis à infecção.

A omissão do diagnóstico ao companheiro pode estar condicionada ao medo da discriminação que as mulheres sentem face ao caráter estigmatizante dessa enfermidade. $\mathrm{O}$ sentimento de uma depoente de 
que poderia ser desprezada pelo companheiro, ao contar sobre sua soropositividade ao HIV, a levou a manter o sigilo, optar pelo término de um relacionamento de 2 anos, depois de ouvi-lo rotular sua vizinha de "aidética".

\begin{abstract}
"Ele era negativo, fiquei 2 anos com ele, mas sempre usando camisinha. Nem sempre ... Como fiquei grávida da Fabiana? Não usei ... nós tínhamos chegado do baile, eu estava um pouco "alta" e ... foi ...sem camisinha! ... Eu nunca tive necessidade de contar, mas depois que eu vi ele xingando uma moça de aidética ... aí piorou a situação. Eu não contei mesmo, preferi terminar o casamento e saí fora." E7
\end{abstract}

"Eu só contei prá ele que estava gestante, não contei o que eu tinha." E7

Com relação à ocorrência da gravidez mesmo com o uso do preservativo, pode-se levantar a hipótese do uso incorreto, como verifica no relato abaixo. "Sempre usei preservativo direitinho, nunca
estourou, mas lá na praia a camisinha estourou e eu
fiquei grávida" E7

Remien (2002) verificou, a partir de trabalhos clinicos e pesquisa que tem conduzido, que mesmo havendo disposição para a adoção do preservativo, ocorre uso intermitente e incorreto do método.

No serviço em que foi realizado o estudo, a orientação às mulheres com aids para evitar a gravidez e prevenir a ocorrência de doenças sexualmente transmissíveis está centrada apenas na utilização de preservativos. Considerando as falas das mulheres, relativas à freqüência de incidentes com o uso do preservativo e às dificuldades de negociação para o 
seu uso, indaga-se sobre a necessidade de orientação a respeito de outros métodos anticonceptivos, que podem ser adotados complementarmente para as mulheres que não desejam engravidar.

"O governo dava camisinha feminina, era boa, acho mais segura que a masculina, hoje em dia você vai procurar, não tem. Eu acho que protege mais, não tem como estourar". E8

Arilha (2002) afirma que a cristalização das práticas de gestão emperra a integração de políticas, programas e estratégias de ação, gerando pulverização dos recursos. A intersetorialidade vai além das áreas de saúde e educação sendo necessária a ampliação das parcerias para redução da vulnerabilidade gerada pela epidemia

\section{Sentimentos presentes no período da gravidez}

As falas das entrevistadas revelaram os diversos sentimentos que permearam a gravidez. Em mais de um discurso esteve presente o sentimento de medo por diferentes razões, um deles o medo de que o seu diagnóstico, que vinha sendo mantido em segredo, se tornasse público.

A mulher soropositiva ao HIV, ao não expor seus sonhos sobre a maternidade, experimentaram sentimentos ambivalentes como o "desejo" e o "não poder" ser mãe, que orientam seus comportamentos e resultam em uma gravidez não planejada, aumentando o risco de transmissão do vírus para a criança, potencializando a vulnerabilidade de ambos.

Neves (2005, p. 93) registrou em sua pesquisa que o silêncio em relação à infecção impede a pessoa de compartilhar suas necessidades com outros e receber ajuda no enfrentamento das dificuldades. Esse 
comportamento prejudica a adesão ao tratamento devido à preocupação em tomar os medicamentos na presença de outros, tornando público o diagnóstico.

Vale esclarecer que as gestantes portadoras do HIV são atendidas em serviços especializados, o que requer muitas vezes justificar por que não fazem o pré-natal no serviço de saúde mais próximo à sua residência. Outro fator que as diferencia de outras gestantes é a ingestão de vários medicamentos durante a gravidez.

"Olha, eu acho que não. A única diferença que eu vejo é porque não é como uma gravidez normal em que você não tem nada. É uma gravidez em que você tem que cuidar, tomar remédios, todo mês uma ou duas vezes você tem que passar no médico." E1

"Na internação para o parto você diz que está com problemas de pulmão, porisso de tanto remédios." E7

Um outro sentimento que emergiu das verbalizações das mulheres entrevistadas foi o de rejeição. Nos depoimentos, as mulheres revelaram o preconceito que vivenciam devido à doença. Sabe-se que a ocorrência dessa enfermidade vem cercada de estigmas, preconceitos e hostilidades por parte da sociedade, que se traduzem por atitudes veladas de condenação e punição, contribuindo para que a mulher seja vista como "incapaz" de gerar filhos em função de ser portadora do HIV.

De acordo com a análise de Guimarães e Ferraz (2002), se algumas pessoas, sob certas circunstâncias, ultrapassarem a linha divisória que as separa da rede de normas, códigos e comportamentos de um grupo/sociedade hegemônico, que circunscreve de forma simbólica ou concreta 
territórios de normalidade, instala-se um desvio que é acompanhado de acusação, isolamento, rejeição e até mesmo punição.

"Ela (mãe) tem muito preconceito das coisas, de tudo, não dá prá conversar sobre isso. Não tenho aonde ir. À noite fico só com meus filhos, moro no quintal dela, mas conviver com ela não." E6

Observou-se que a discriminação aumenta quando engravidam, porque no imaginário social, a mulher portadora de uma doença como aids está condenada e não deve engravidar, pois não tem condições de criar um filho.

Zihlman (2005), em seu estudo, verificou que o desejo de ser mãe em pessoas com aids é interpretado como uma decisão impensada, "de mulher doida", embora as mulheres afirmem que lhes é de direito ter filhos, se quiserem arriscar.

Percebe-se nas falas das mulheres focadas neste estudo que não se sentem incapazes de ser progenitoras, e querem assim, ser reconhecidas, bem como exercitar o direito de cidadania no tocante ao processo reprodutivo.

"Mesmo sendo portadora do vírus, eu falo para todas as mães se cuidarem e terem seus filhos, porque isso não vai ser empecilho. Se eu tive e consegui vencer, outras também podem." E7

"Acho que é normal, a mesma coisa de uma mãe saudável." E8 
O estudo de Ruggiero (2000) também atesta situações de preconceito vividas pelas gestantes entrevistadas. Por mais que tentem conviver com a discriminação, não conseguem evitar os pensamentos negativos tais como: o medo de rejeição social, o aborto como uma solução, o risco da transmissão para o filho, a culpa pela possibilidade de morte prematura, acompanhada de um sentimento de insegurança quanto ao futuro dos filhos.

Conforme Zihlmann (2005), as mulheres percebem que o olhar que o outro tem sobre o fato de ela ser soropositiva e mãe é um olhar crítico e preconceituoso.

O relato abaixo expressa o medo do preconceito, o que resulta no ocultamento do diagnóstico.

"Tem muita gente que não aceita o fato de um colega, ou alguém da família ser soropositivo; da minha família ninguém sabe; só a família dele (parceiro)" E1

Algumas sentiram-se rejeitadas e discriminadas ao receberem reprovações de profissionais dos serviços de saúde, em razão da gravidez. Uma das mulheres relatou que, durante o atendimento, o profissional médico a questionou sobre sua irresponsabilidade pela gravidez na situação de soropositiva ao HIV. A depoente considerou lamentável que o comentário tenha sido feito em público, na enfermaria, na presença de outras pacientes, quando foi atendida, em um hospital, em decorrência de um aborto, ao mencionar que era soropositiva. 
"Quando eu sofri um aborto, (...) eu fui para o pronto-socorro com hemorragia. Os médicos falaram: por que eu não usava camisinha? Eu era irresponsável de ter filho,... para o mundo criar. Ele gritou prá todo mundo ouvir." E4

O plano programático da vulnerabilidade ao adoecimento pode ser avaliado pela qualidade da assistência. Assim, a vulnerabilidade pode ser afetada pelo modo inadequado como o profissional atende seu paciente.

As mulheres entrevistadas narraram, espontaneamente, situações em que foram tratadas com hostilidade por profissionais da saúde em hospitais ou pronto-socorros. Segundo elas, houve tratamento agressivo revelador de ostensivo preconceito contra mulheres portadoras de HIV que ousaram engravidar. Algumas referiram ter recebido acusações veladas, em postos de saúde, por terem se permitido gerar filhos na condição de soropositivas. Isso deu-se na forma de comentários feitos em tom galhofeiro: "Outra vez grávida?" "É isso mesmo que você quer?" "Que loucura!"

"Eu encontrei uma pessoa conhecida aqui, fiquei com medo de ela começar a contar para as pessoas conhecidas, pedi transferência. Me mandaram lá para a Penha, a médica me tratou assim... parece que com nojo, com desprezo. Como ela não estava com luvas, pegava o papel da cama prá me examinar....me senti um lixo." E15

Ayres et al. (1999), tratando de vulnerabilidade, aponta a ênfase nos Direitos Humanos como fonte de critérios objetivos para avaliar as situações individuais até a situação global em face da epidemia aids. O autor explicita que:

[...] além da definição das ações e condições a que os indivíduos devem ter acesso, o movimento pelos Direitos Humanos deve definir aquelas a que os indivíduos não poderão ser expostos, ou seja, a defesa de uma inalienável esfera de autonomia e competência 
própria a cada indivíduo (person's agency), livre de ameaças ou constrangimentos, dentro dos limites impostos pelos direitos do outro.

Outro medo que se desvelou em suas falas é com relação à transmissão vertical, que pode ocorrer durante a gravidez ou no parto. Esse temor perdura até cerca dos 18 meses de vida do bebê, período em que é possível ter um diagnóstico definitivo. Os fragmentos abaixo atestam esse sentimento:

"Aí começou tudo de novo aquela perturbação na cabeça: e se a minha filha tiver o vírus? E3

Esse tipo de medo é acompanhado pelo sentimento de culpa pela transmissão do vírus, como se pode constatar no relato :

"Eu acho que se acontecer alguma coisa com as minhas filhas a responsabilidade é minha. Elas nem viveram ainda para ter um problema desses, ficar tomando remédio. O que eu fiz da minha vida." E9

Outras manifestações demonstram sentimentos de preocupação com a ocorrência de má formação da criança durante a gestação:

"Porque você se sente com medo. No meu segundo filho, tinha medo de ele nascer defeituoso." E6

Zihlmann (2005), em seu estudo, encontrou mulheres com receio de que seu filho nascesse defeituoso, dado que uma criança com má formação congênita pode ser gerada por uma mãe defeituosa, reafirmando a anormalidade na pessoa com HIV. 


\section{Repercussões da gravidez no cotidiano das mulheres}

Ao indagar se as entrevistadas percebiam diferenças entre a gestação que ocorreu antes da soropositividade e as posteriores, a maioria referiu que, num primeiro momento, não houve diferenças. Ao reforçar a pergunta, algumas relataram que a única diferença diz respeito à medicação, que compreende a introdução ou alteração dos anti-retrovirais para proteção da criança, como se vê no discurso a seguir:

"A diferença? Eu acho que são as medicações que você tem que tomar ..., são muitas medicações e você não pode falhar nenhuma, porque se você falhar em uma ... você pensa na criança”. E16

"É bem diferente uma mãe normal de uma soropositiva. Não que seja ruim, é só um pouquinho mais difícil. Ela vai ter só mais cuidados, muita medicação, só isso." E7

Uma das mais significativas mudanças que a gravidez provocou no cotidiano das mulheres entrevistadas foi a melhora na adesão ao tratamento. Esse efeito positivo foi observado nos relatos e, também, comprovado pelos registros constantes nos prontuários.

Várias depoentes só apresentaram adesão ao tratamento medicamentoso quando engravidaram.

"No começo da gravidez eu estava com o vírus muito alto, porque não estava me tratando. Estava com pneumonia, comecei a tomar a medicação e depois de 3 meses de gestação, meu vírus já estava indetectável." E3 
Apesar da credibilidade na eficácia da medicação profilática para impedir a transmissão vertical, verificou-se descrédito no tocante ao efeito do tratamento no controle da evolução do seu processo saúde-doença.

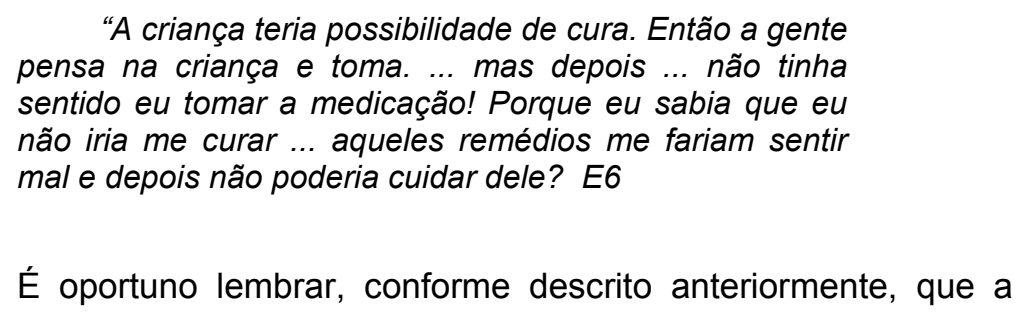
adesão ao tratamento foi maior no período da gestação e após o nascimento do filho. Assim, pode-se considerar a gravidez como um fator potencializador da adesão, redundando em maior redução à vulnerabilidade ao adoecimento dessas mulheres.

O discurso subseqüente apresenta as intercorrências relativas à medicação que marcaram, como uma das etapas mais difíceis dessas mulheres com aids, o período gestacional.

\footnotetext{
“Eu tive estes problemas com o remédio,... meu organismo não estava aceitando. Eles trocaram três vezes." E16
}

Pelos discursos, observou-se que estar grávida na condição de soropositiva ao HIV foi diferente, pois exigiu maiores cuidados com sua própria saúde, necessitando iniciar tratamento com anti-retrovirais e repouso, pois apresentou risco de aborto.

"Não é como uma gravidez normal em que você não tem nada, você tem que se cuidar, tomar remédios. Foi uma gestação de alto risco." E1 
O discurso a seguir exemplifica o quanto a gravidez mudou o cotidiano da entrevistada para melhor. Antes ela passava por várias internações, durante a gestação não houve intercorrências.

"Eu ficava sempre ruim antes. Foi melhor com a gravidez. A médica falou que quando eu fico grávida eu fico mais forte, mais gorda, parece que eu tenho mais força." E9

\subsubsection{A expressão da maternidade}

Os significados atribuídos à maternidade - tema central deste estudo - revelam que ser mãe agrega valor afirmativo de viver com aids, o que se percebe nas falas das mulheres e nas expressões não verbais verificadas durante as entrevistas. Expressões faciais que denotavam satisfação, alegria, seguidas de momentos de silêncio, quando buscavam palavras para traduzir os significados da maternidade em suas vidas.

Assim a condição de "ser mãe" foi definida como "algo maravilhoso", "um privilégio”, "um dom de Deus”, "muito gratificante”, "é tudo” e "a realização de um sonho",

Zihlmann (2005), em seu estudo, afirma que um filho "saudável e perfeito" garantiria a "superação" dos malefícios de ser portadora do HIV, possibilitando um "resgate narcísico da mãe", isto é, a mãe, espelhando-se no filho, vê a si própria como uma mulher saudável.

Conforme Silva (2003), na sociedade ocidental contemporânea, ter filhos e cuidar dos mesmos faz parte da expectativa social. Para Heilborn; 
Gouveia (1999), o exercício da maternidade pode configurar uma identidade social, entendida como um conjunto de marcas sociais que conferem um status ao sujeito em uma determinada sociedade, a partir de três dimensões: da inserção na estratificação social, idade, gênero, etc; das inter-relações dinâmicas entre esses eixos classificatórios; dos valores que se corporificam em significados articuladores da imagem de si e a relação com o outro.

Na vida reprodutiva dessas mulheres, o significado conferido à maternidade pode ter predominância em relação ao valor atribuído à identidade em torno do HIVIAIDS, o que sugere um estado de ânimo que re-significa a doença e a vida, afetando positivamente a vulnerabilidade.

Nesse sentido, vale lembrar que a mulher, quando recebe o diagnóstico soropositivo ao HIV, tem suas auto-referências comprometidas: passa a se isolar, preocupa-se em manter a doença em segredo, tem sentimentos de apreensão com a possibilidade de morte iminente, abandona sonhos e projetos pessoais para o futuro, concentrando-se no momento presente.

O advento da maternidade possibilita-lhe o resgate de sua identidade, como mulher, na sociedade, uma vez que passa a exercer os mesmos papéis das outras mulheres, enquadrando no conceito de normalidade. Essa auto-imagem positiva, reflexo do que a sociedade estabelece como "normalidade", possibilita a capacitação para um melhor enfrentamento da doença, contribuindo com a redução de sua vulnerabilidade.

Para Knauth (1999), as mulheres infectadas pelo HIV conseguem assegurar, por meio da gravidez, o status de mãe e a identidade 
social ameaçada pela doença. O diagnóstico de soropositiva ao HIV não implica o encerramento da atividade reprodutiva. A maternidade vem identificálas como "mulheres de respeito", cujo comportamento não pode ser questionado.

\section{Dificuldades após o nascimento dos filhos}

Adentramos agora em uma sub-categoria, que abrange as dificuldades enfrentadas após o nascimento da criança: manter sigilo sobre os diagnósticos materno e infantil, não poder amamentar a criança, convivência com o diagnóstico temporário da sorologia ao HIV da criança, insuficiência de recursos financeiros para possibilitar uma vida digna, abandono/separação ou morte do companheiro, preocupação com o futuro das crianças se a mãe adoecer, enfrentamento da discriminação. Observe-se que essas dificuldades são genéricas, pertinentes a qualquer mulher e não somente às portadoras do HIV.

Em relação a confidências sobre o diagnóstico da doença, muitas mulheres informaram terem permanecido com o segredo dentro da família e círculo de amigos próximos por vários anos, sem revelar à sociedade. Esconderam a condição de portadora até o momento da entrevista, a maioria delas já estava com 5 a 12 anos de diagnóstico e somente o companheiro e a mãe sabiam da doença. Ocultavam a condição de portadora de HIV, para não enfrentarem o preconceito que também se estenderia ao filho. Essa situação as obrigava a criar falsas razões e forjar doenças que justificassem a ingestão de medicamentos profiláticos por parte da criança. Ao que se sabe, o ocultamento da doença perdura até o presente. A esse respeito, vê-se o relato abaixo: 
“Ela (ajudante) não sabe. Eu sempre falo que é um remédio que ela tem que tomar desde que saiu do hospital. Mas nunca falei prá ela do que se trata." E8

Nas palavras de Knauth (1999), as mulheres soropositivas tendem a manter sua condição como um "segredo bem guardado" e que só pode ser divulgado em condições muito especiais ou que tragam alguma vantagem, em face do grande receio de se exporem socialmente.

Para resguardar o seu diagnóstico, as mulheres soropositivas procuravam justificativas quando familiares e amigos questionavam por que a criança não era amamentada no peito.

Além de ser difícil justificar, sem revelar a soropositividade, havia uma sensação de culpa e tristeza por não poder dar a oportunidade de amamentação a si e à criança. O discurso a seguir mostra que não amamentar lembra a aids, a mamadeira diminui o contato físico e provoca medo de ser julgada pelo próprio filho, posteriormente..

"O ruim é que os outros perguntam por que você não pode estar amamentando o seu filho. Você já fica pensando: eu estou com aquele problema, já não posso dar de mamar para o meu filho. Não posso dar carinho. Tem de ficar logo cedo mamando mamadeira. O que ele vai falar quando crescer?" E9

"A gente quer dar de mamar para a criança, sentir mais a criança. ... eu tinha muito leite, doía muito não amamentar. Eu fiquei muito triste mesmo..." E11

"É ruim estar com ele no colo e todo mundo amamentando e você não poder. Acho que corta um pouco do vínculo de mãe e filho." E9 
Knauth (1999) considera que o fato de as mulheres infectadas não poderem amamentar seus bebês é o primeiro anúncio da aids, a qual, se não aparecia nem física, nem socialmente, até aquele momento, com a não amamentação pode ficar a descoberto. As mulheres se vêem obrigadas a apresentar uma justificativa convincente.

Analisando-se os dados sob o ponto de vista da vulnerabilidade individual, nos aspectos cognitivos-comportamentais, enxergamos, como elementos protetores às mulheres do estudo, a tomada de consciência do problema e a habilidade que desenvolveram para construir atitudes e ações de enfrentamento à doença, por meio de comportamentos mais saudáveis e de enfrentamento às situações de preconceito.

A fala que se segue nos mostra a necessidade de omitir o diagnóstico para proteger os filhos do preconceito na escola, nos primeiros anos de vida, quando a mãe comunicou sobre a possibilidade de sua filha ser HIV+, já que estava em acompanhamento clínico na época.

" A gente não tinha certeza, e eu pus ela na creche, e contei para a professora. Ela não queria pegar. Quando pegou, deixava a menina afastada das outras crianças. A pediatra dela me informou que eu não tenho que contar para ninguém." E16

Uma outra entrevistada comentou sobre as justificativas que aprendeu a dar e que passou a transmitir a outras mães, quando são questionadas sobre o porquê de a criança estar tomando o AZT xarope.

"Por que seu menino toma aquele xaropinho vermelho? É porque já nasceu com probleminha de 
pulmão, graças a Deus as enfermeiras contam sempre a mesma história, e tudo dá certo." E7

Landroni (2004) comenta sobre a dificuldade de as mulheres se colocarem como sujeitos no espaço assistencial. Em seu estudo, as mulheres sinalizaram a necessidade da incorporação de estratégias que Ihes possibilitem falar e aprender a lidar com a doença e de que haja uma abordagem de outros aspectos associados, como o medo do preconceito e discriminação, que estão além do controle clínico da infecção.

Acresce-se a necessidade de justificarem aos familiares, amigos e vizinhança a razão de tanto medicamentos, no período de internação pós-parto na enfermaria ou no domicílio.

"Todo mundo vai notar que você toma remédios a mais no hospital..., às vezes são bastantes, 6 coquetéis , eu falo que é da pressão, mas e os outros? Falo também que é problema do pulmão, por isso que o bebê tem que tomar também, ... você associa, né. Eu não tenho que dar explicação, mas já que estão pedindo, você dá essa explicação e tudo dá certo".E7

As mulheres relataram ter sido difícil conviver com a expectativa do diagnóstico da criança. Os dois primeiros anos de vida, período que requer um acompanhamento clínico e laboratorial mais frequente, para avaliação do desenvolvimento da criança e da evolução sorológica ao HIV, são marcados por uma convivência permeada por sentimentos contraditórios, como a confiança, medo e ansiedade. Por um lado, há uma confiança de que não ocorreu a transmissão do HIV à criança, dada a credibilidade na eficácia do tratamento preventivo durante a gestação, no parto e no pós-parto. Ancorada na fé em Deus, há a crença em uma providência divina que impediu o 
acomentimento da criança pela doença. Por outro lado, a possibilidade da transmissão invade seus pensamentos e produz apreensão, medo, insegurança, impotência e ansiedade, face à demora para se ter um diagnóstico definitivo.

O diagnóstico final, expresso na sorologia negativa ao HIV, gera sentimentos de fortalecimento, de vitória e de compensação pelo esforço empreendido:

"É um pouco diferente, se fosse um bebê comum ninguém estava perguntando. Quando negativa é uma felicidade! Você se esforçou, mereceu! Você é uma vencedora!" E7

A condição de portadoras do HIV, mesmo na ausência de sinais e sintomas, constitui uma outra dificuldade para as mulheres, dada a preocupação quanto ao futuro dos filhos. Vem a seguir uma exemplificação:

"Eu tenho medo de cair, estou sempre tentando fazer as coisas para não ficar doente, penso neles que dependem de mim. Tenho medo de eles ficarem sozinhos, porque o pai já não liga." E12

A falta de acolhimento e receptividade ao infectado por parte dos familiares e amigos pode aumentar a vulnerabilidade ao adoecimento. A ausência de apoio familiar e/ou estar sem o companheiro é um dos problemas enfrentados na opinião das mulheres entrevistadas. O discurso transcrito a seguir é representativo das falas de outras mulheres que se encontravam sozinhas, sem companheiro ou família e desempregadas.

"O que muda? Sou sozinha, caso aconteça alguma coisa comigo, com quem vou deixar as crianças? E9 


$$
\begin{aligned}
& \text { “É, prá criar sozinha..., ser a mãe e o pai ao mesmo } \\
& \text { tempo.... .E5 }
\end{aligned}
$$

Conforme Mello Filho (2004), em quase todas as espécies cabe às fêmeas a criação dos filhos; contudo, o suporte de algum adulto masculino é importante não só na esfera econômica, mas para que os filhos se identifiquem com ele e obtenham bom êxito como homens.

As entrevistadas enfrentavam a situação do desemprego e em conseqüência, os recursos eram insuficientes para cuidar dos filhos. Há um caso em que a mulher tinha dificuldades de trabalhar devido aos filhos serem pequenos, e não ter acesso a creches. Ela se mantinha com doações dos vizinhos.

\footnotetext{
"Eu não consigo arrumar alguém para ficar com o pequeno. Se ficassem pelo menos com o menor, a maior eu dava um jeito.".E5

O desemprego foi um fator importante nas dificuldades
} enfrentadas por essas mulheres, que antes de terem filhos estavam inseridas em serviços informais, sem registro em carteira. Pode-se reportar ao capítulo deste trabalho que trata do perfil dessas mulheres, onde apenas duas possuíam registro em carteira. Anteriormente ao nascimento dos filhos, apenas uma perdeu seu registro em carteira, devido à apresentação de atestado. Os motivos principais do desemprego foram a baixa escolaridade e o cuidado com a doença.

Acrescente-se que existe o receio de ter sua doença revelada por exames pré-admissionais ou por constantes ausências ao trabalho para realizar os exames de controle da evolução do processo saúde-doença e 
freqüentar as consultas médicas ou outras atividades oferecidas no SAE, necessárias ao acompanhamento do seu processo saúde doença.

"Quando eu fiquei grávida dela eu não estava trabalhando mais,(...) mesmo se eu quisesse, tem muitos serviços que pedem exames e eu tenho medo de fazer o exame e constar e eles não me aceitarem." E1

De acordo com Ayres et al. (1999), entre as condições que afetam a vulnerabilidade individual estão as de ordem social que se referem ao acesso a recursos e poder para adotar comportamentos protetores.

Algumas das mulheres entrevistadas tiveram, no decorrer da gestação e nascimentos de seus filhos, situações de morte do companheiro na maioria das vezes não relacionadas com a doença aids, mas por assassinatos. Das dezesseis mulheres entrevistadas, quatro tiveram seus companheiros assassinados, cinco estavam separadas e os maridos de duas delas faleceram por outros motivos.

“.. a da terceira foi uma gravidez complicada. O pai dela faleceu com três meses. Foi na época que eu descobri que estava com esse problema. Quase cometi um aborto com ela" E9

Ainda nessa categoria, destacam-se como relevantes, nas falas das mulheres estudadas, os sentimentos de rejeição e discriminação por terem engravidado, resultantes de atitudes preconceituosas, hostis e desrespeitosas dos profissionais da área da saúde.

Na categoria "a expressão da maternidade", pela observação empírica dos depoimentos das mulheres selecionadas para este estudo, 
encontramos, ao lado dos sentimentos de preocupação com o futuro e desamparo familiar, a percepção de que, com a maternidade, sentiram-se mais fortalecidas biológica e emocionalmente. Isso sugere que a maternidade não se caracterizou como determinante de maior vulnerabilidade ao adoecimento de uma mulher com aids, porque a dimensão individual é composta por outros componentes que a vulnerabilizaram em situação de mãe ou não, como: o preconceito, a discriminação, as preocupações com o sigilo sobre a doença, os problemas financeiros, estar sozinha, o desemprego, a inadequação dos métodos contraceptivos, más condições de moradia e a baixa escolaridade, todos anteriores à maternidade. Verbalizaram melhora do estado emocional; sentiram-se reconhecidas no papel de mulher mãe/esposa, realizadas, motivadas para a adesão ao tratamento, capazes de gerar e criar seus filhos, o que lhes trouxe estímulos, sonhos e expectativas para o futuro.

\subsubsection{As Implicações da maternidade no cotidiano das mulheres}

A maternidade traz uma melhor adesão, melhor cuidado de si e um melhor relacionamento familiar expresso em uma maior união da família.

Nos relatos transpareceram como implicações da maternidade: revisão de valores, tomada de posição em relação ao seu processo-saúde doença e desenvolvimento de novas formas de poder e de enfrentamento das situações de discriminação. 
Podemos verificar que a maternidade produz mudanças que promovem a construção de novos valores e adoção de comportamentos que resultam na melhoria da qualidade de vida criando estratégias para enfrentamento da doença e seus desdobramentos. Veja-se o fragmento de um dos discursos:

“ Hoje eu sou mais plena, ... meus sonhos não são mais aqueles a longo prazo, hoje eu penso em viver cada dia, sem deixar nada pendente, me dedicar mais a eles (filhos) (...) E4

A melhora do cuidado consigo própria foi referida pelas mulheres como uma prática necessária em função da sua responsabilidade pelos cuidados com o filho(a).

"Os filhos, eu tomo os remédios por eles, os filhos te acrescentam coisas boas de você querer melhorar, ajudar eles, porque se você ficar doente, ... com HIV no final, não pode" E7

"Antes da gestação da última neném, tive complicações porque, fiquei um ano sem me tratar e depois eu voltei o tratamento, em seguida eu engravidei, e tive pneumonia, estava com uma série de complicações, com o vírus HPV, estágio 1 ainda, mas fiz o tratamento tanto o ginecológico, como com o doutor. Me recuperei muito rápido, foi uma coisa que nem o médico mesmo acreditou.E3

O nascimento do filho constituiu um fator de fortalecimento no enfrentamento do processo saúde-doença como se pode evidenciar na frase seguinte:

"Antes eu ficava doente, internada, tristonha, com depressão. Depois que eu tive meu filho, na, tive mais depressão." E8 
A maternidade re-significou a vida das mulheres do grupo de estudo. Os filhos passaram a representar uma forte razão para continuar vivendo.

"Acho que nem estaria viva, só eles (filhos) mesmos para me reerguer."E1

No discurso abaixo, a mulher contrapôs o efeito positivo da maternidade em sua vida ao efeito negativo de saber-se portadora de HIV. Ser mãe neutralizou o impacto da aids em suas vidas.

"Ser mãe sendo HIV positivo, você já tem um ponto negativo, o que a gente faz? Tem que lutar pra ficar tudo positivo, pra esse ponto não ser tão grande e não atrapalhar o resto. Os bebês são esses pontos positivos." E7

As falas das mulheres do estudo traduzem que se sentem mais fortalecidas por terem filhos. Eles motivaram-nas a uma maior adesão ao tratamento, a praticarem o autocuidado, impondo mais disciplina em suas vidas, adquirindo novos hábitos. Passaram a ter mais responsabilidade, maior cuidado com a sua aparência, a dar maior atenção à medicação, à alimentação $e$ às horas de sono.

"Não é porque eu sou doente que eu vou me largar, eu me cuido (...) o que eu puder fazer na minha condição eu faço. (...) eu tenho marido que não é (soropositivo), eu me protejo na hora que a gente tem relação, mesmo depois que a gente teve as crianças e eu fiz laqueadura." E16

"Quando você tem filho você liga para a alimentação, liga para fazer comida boa para seus filhos, que acaba sendo boa prá você e prá sua saúde" E7 
"Vivo em função deles mesmos, totalmente, por isso eu faço meu tratamento direito." E4

Com a advento da maternidade, estabelecem-se novas formas de poder relacionadas ao papel de mãe. É com orgulho que as pacientes referem-se a responsabilidades inseridas no seu cotidiano após o nascimento dos filhos.

Cunha (2004, p.17) concluiu em seu estudo com mulheres com aids, que os filhos dão um sentido a suas vidas, em uma estreita relação entre cuidar-se e cuidar dos filhos. "O autocuidado significa afirmação da vida, é não querer entregar-se à depressão."

"Uma mãe de verdade se preocupa com seus filhos, não quer ver seus filhos passando necessidade, é uma obrigação minha, agora dele (parceiro) eu não sei." E8

O tornar-se mãe agrega mais a família, como se pode comprovar pela fala abaixo:

"Depois que ele nasceu, todo mundo aqui em casa ficou mais unido. Foi muito boa a vinda dele, a gente brigava muito, a gente se uniu mais, até as meninas." E8

Vê-se por esse depoimento que a perspectiva de ser mãe trouxe a oportunidade de realizar o ideal de reconstituir uma família, tendo eleito o atual companheiro para essa nova fase. A maternidade, ao mesmo tempo em que consolidou esse desejo, indicou novos rumos para sua vida.

Rohden (2000, p.70 ) refere em seu estudo que "O modelo de família composta por pai, mãe e filhos é pensado como base, a partir da qual 
se estruturam as nossas relações de parentesco, de sociabilidade, de pertencimento a determinados grupos."

Consoante Knauth et al (1999), a família está no centro do valor simbólico do grupo, representando um elemento fundamental de determinação de identidade social. Nessa perspectiva, as decisões sobre procriação vêm permeadas pelo valor-família, mesmo no caso das mulheres portadoras de aids.

Falcke; Wagner (2000) verificaram em seu estudo, com mães e madrastas, que as mães têm uma visão histórica da mulher como responsável pelas funções de cuidadora, educadora e suporte afetivo.

A mudança na forma de acolhimento das mulheres no SAE e maior recebimento de apoio familiar após a maternidade denotam uma redução da rejeição adquirida com o diagnóstico da aids. O vínculo com os médicos aumenta, pois além do acompanhamento com o infectologista, são incluídas na sua rotina as consultas mensais com ginecologista durante o prénatal e com o pediatra após o parto.

A equipe de saúde responsável pelo atendimento no SAE é multiprofissional, mas a assistência segue o modelo médico centrado, em que este é elemento nuclear e os demais profissionais são considerados de apoio, reforçando o distanciamento entre usuários e os outros membros da equipe, limitando e fragmentando a assistência prestada. 
Segundo Silva et al (2002), o trabalho multiprofissional só se configura quando são apreendidas as necessidades dos usuários pelos profissionais.

Há uma melhora na aceitação social da mulher com aids, um apoio dos profissionais para essa nova fase da sua vida agora com filhos, ou melhor, mais um filho.

Uma outra implicação da maternidade constatada foi voltar a ter sonhos, ter esperança. Sonhos iguais ao de qualquer outra mulher, como: ter uma casa, poder criar os filhos, oportunizar aos filhos uma formação escolar.

Finalizando esta parte da pesquisa que se refere às discussões de dados, é pertinente falar dos sonhos desse grupo de mulheres, os quais, na verdade, estão no imaginário de todas as mães de família. Todas se reconhecem no desejo de ter casa própria, de proporcionar a educação escolar para os filhos, de vê-los encaminhados, independentes. Contudo, para essas mães em especial, a aspiração máxima é a própria cura e a esperança de que seja revertida a situação de HIV- dos filhos que ainda estão com o diagnóstico em suspense por conta da pouca idade. As que têm filhos soropositivos cultivam o sonho de vê-los livres da doença. Depoimentos contundentes falam por si:

"Tenho um sonho: construir em cima da casa da minha mãe.

(...) É o meu sonho, só ter uma casinha maior." E1

"Meu sonho é dar uma vida boa para elas, para não passarem o que eu passei." E9 
“(...) Encaminhados, estudados, deixar alguma coisa prá eles.” E12

"É meio difícil, mas eu espero que eles encontrem uma cura pra isso. (Falando de si mesma)"E12

"Eu tenho esperança que ela negative (2a filha de 4 anos, soropositiva), embora a médica diga que é difícil, falou que não há possibilidade, mas eu espero que possa. "E4

A qualidade do apoio aos portadores de aids, no momento do diagnóstico, influenciou as intenções de maternidade, dimensão que encontra mais obstáculos para ser acolhida, conforme atesta o estudo de Paiva (2000). Os programas de saúde podem minimizar as condições de vulnerabilidade ao adoecimento, dispensando um aconselhamento quanto ao que se refere ao melhor momento para a gravidez no aspecto clínico, com relação ao nível ideal de carga viral e proteção imunológica. 
Este estudo teve como finalidade subsidiar o planejamento de intervenções voltadas para as mulheres com HIV, na perspectiva do conceito de vulnerabilidade, após conhecer os significados que as mulheres atribuem à maternidade e as implicações de ser mãe, no processo saúde-doença, depois do seu diagnóstico da aids.

Considerando que a maioria dos estudos existentes trata da gravidez em mulheres com aids, sem contemplar o significado e as implicações da maternidade para elas, acredita-se que este estudo vem acrescentar ao acervo de pesquisas sobre aids, informações sobre ser mãe para essas mulheres, o que elas têm a dizer sobre suas experiências em ter filhos e cuidar deles e de si própria.

Os resultados da análise das características sóciodemográficas das mulheres do estudo reiteram as condições de vida como condicionantes da vulnerabilidade ao adoecimento pelo HIV, no tocante à dimensão individual, caracterizada por: baixa escolaridade, desemprego, insuficiência de recursos financeiros, dificuldades com transporte até o SAE, e falta de vagas em creches em suas regiões.

O estudo também permitiu compreender como as mulheres portadoras do HIV vivenciaram a maternidade e como esse estado - ser mãe condicionou o enfrentamento do processo saúde-doença, considerando seu contexto de vida, incluindo aqui suas condições sócio-econômicas, suas 
percepções, crenças, conhecimentos e o cuidado que os serviços de saúde lhe oferecem.

As hipóteses para o estudo foram confirmadas, a maternidade fortaleceu as mulheres no enfrentamento do processo saúde-doença, ao atribuir-Ihe um sentido positivo; ter alguém sob sua responsabilidade, o filho, contribuiu para que suas vidas passassem a ter um novo significado. $\mathrm{Na}$ percepção das mulheres, a maternidade interferiu de maneira benéfica no cuidado consigo própria e, conseqüentemente, do processo saúde-doença. Ainda, a maternidade Ihes trouxe possibilidades de resgatar sua identidade na sociedade, como mulher, e seus direitos como cidadã.

A vivência da maternidade promoveu, nas mulheres do estudo, a re-significação da aids, do risco da transmissão vertical do HIV e da vida.

O material empírico oriundo das falas das mulheres possibilitou a construção de três categorias: "a vivência da gravidez", "a expressão da maternidade" e "as implicações da maternidade no cotidiano das mulheres".

$\mathrm{Na}$ categoria "a vivência da gravidez", os resultados encontrados corroboram os achados de outros estudos, de que na ótica da mulher portadora do HIV, ser acometida por uma doença como a aids não constituiu impedimento para engravidar. Foram desvelados sentimentos de foro íntimo como motivadores da gravidez, entre eles, os sonhos de infância, o desejo de corresponder à expectativa social, a vontade de agradar ao companheiro, a necessidade de auto-afirmar-se como pessoa saudável em contrapartida ao adoecimento pela aids. $\mathrm{Na}$ esfera comportamental, o uso 
inadequado do método anticoncepcional foi responsável por eventos de gravidez não planejada, diferentemente de não desejada.

Ainda nessa categoria, destacam-se como relevantes, nas falas das mulheres estudadas, os sentimentos de rejeição e discriminação por terem engravidado, resultantes de atitudes preconceituosas, hostis e desrespeitosas dos profissionais da área da saúde.

$\mathrm{Na}$ segunda categoria "a expressão da maternidade" constatou-se sentimentos de exaltação à maternidade considerando como um evento altamente positivo em suas vidas, permeados por outros sentimentos, como o de insegurança, culpa e medo frente ao risco da transmissão vertical, receio de morrer e deixar os filhos desamparados. A presença desse sentimento reforça a importância e a necessidade da prática do acolhimento pelos profissionais, para buscar conjuntamente com o usuário, estratégias para o enfrentamento da nova situação. Um acolhimento que contemple às necessidades biopsicossociais dessas mulheres, e se configure pela escuta atenta às questões, relativas as suas demandas reprodutivas, levando em conta seus anseios, seus sonhos, para que sejam apreciados para além do quadro clínico, enfim, a relação que mantêm com o mundo que as cerca.

O preconceito foi permanente na vida dessas mulheres, embora os motivos, secundários à aids, sejam distintos na gravidez e após o nascimento dos filhos. Percebe-se que as mulheres portadoras de HIV desenvolveram estratégias próprias para protegerem a si mesmas e aos filhos de comentários e atitudes preconceituosas e discriminativas e, em alguns 
casos, o auxílio partiu dos profissionais quanto à forma de se sair de situações constrangedoras.

Reportando-se à categoria "as implicações da maternidade no cotidiano das mulheres", as repercussões compreendem benefícios, posto que a maternidade as fortaleceu, uniu a família e melhorou o vínculo com profissionais de outras especialidades, como da ginecologia e pediatria. É válido ressaltar que os efeitos dessa vivência incidem positivamente no controle do processo saúde-doença, isto é, os vínculos possibilitam o trânsito das falas entre os profissionais e a paciente, aproximando-os no reconhecimento das necessidades dessas mulheres.

A experiência de "ser mãe tendo aids" descrita pelas mulheres estudadas revelou situações que condicionam, potencializando ou minimizando, a vulnerabilidade à infecção, adoecimento e morte pelo HIV na mulher e filho.

Os elementos identificados como potencializadores da vulnerabilidade, no contexto da transmissão vertical do HIV, foram: o não compartilhamento de "desejos" relacionados à maternidade; a insuficiência de conhecimentos sobre a doença; a descrença no diagnóstico; o não planejamento da gravidez; o conhecimento tardio do diagnóstico da soropositividade; o não reconhecimento da vulnerabilidade ao HIV; a discriminação e o preconceito nas relações familiares e sociais; discriminação nos serviços de saúde; o desemprego; condições de vida precárias; a perda do companheiro; a falta de apoio familiar; a abordagem insuficiente do processo reprodutivo junto às mulheres com aids. 
Os elementos ou condições identificados como protetores da vulnerabilidade abrangeram: a maternidade; credibilidade na eficácia do tratamento preventivo da transmissão vertical; acolhimento nos serviços de saúde; menor discriminação por parte dos familiares e dos profissionais de saúde; adesão mais constante ao tratamento; mais união com a família, a reconstituição de novo núcleo familiar, fortalecimento da mulher no enfrentamento à doença e a preconceitos, o sentimento de serem amadas pelos filhos sem discriminação; mais responsabilidade e adoção de comportamentos mais saudáveis; maior autocuidado, o retorno da esperança e do sonho.

Uma outra contribuição do presente estudo incide sobre a identificação de dificuldades enfrentadas pelas mulheres na vivência da maternidade, o que pode subsidiar o planejamento das intervenções junto às mulheres portadoras das mesmas condições que o grupo estudado. Além disso, a compartilhamento com os profissionais do SAE, certamente promoverá uma reflexão acerca de suas práticas. As dificuldades mais citadas foram: manter sigilo do diagnóstico para evitar o preconceito, aceitar a restrição de não amamentar a criança, conviver com o diagnóstico temporário do filho, preocupação com o cuidado e o futuro dos filhos face à possibilidade de evolução do seu agravo, a discriminação, dificuldades financeiras, ausência/perda/abandono do companheiro.

Este estudo não se encerra aqui, ele abre caminho para análises mais aprofundadas quanto ao evento maternidade na vida de mulheres com aids. Outros estudos que envolvam a avaliação dos elementos identificados como moduladores da vulnerabilidade ao HIV, na perspectiva da 
TV devem ser desenvolvidos, com vistas a otimizar a assistência à saúde, contribuindo para a melhoria da qualidade de vida das mulheres que vivem com HIVIAIDS. 


\section{REFERÊNCIAS}

Aguiar JM. Mulheres Aids e os serviços de saúde: interfaces [dissertação]. Rio de Janeiro: Escola nacional de Saúde Pública, Fundação Oswaldo Cruz; 2004.

Arilha M. Políticas públicas de saúde, mulheres e DSTs/AIDS: reajustando o olhar. Rio de Janeiro: ABIA; 2001. (Coleção ABIA - Saúde Sexual e Reprodutiva, v. 4).

Arras JD. Aids and reproductive decisions: having children in fear and trembling. Milbank Q. 1990;68(3):353-82.

Ayres JRCM, França Júnior I, Calazans GJ, Saletti Filho HC. Vulnerabilidade e prevenção em tempos de aids. In: Barbosa RM, Parker R, organizadores. Sexualidade pelo avesso: direitos, identidades e poder. São Paulo: Ed. 34; 1999. p. $50-72$.

Barbosa RM, Knauth DR. Esterilização feminina: AIDS e cultura médica: os casos de São Paulo e Porto Alegre, Brasil. Cad Saúde Pública. 2003;19 Supl 2:365-76.

Bardin L. Análise de conteúdo. Lisboa: Edições 70; 1977.

Berlinguer G. A doença. São Paulo: Hucitec; 1988.

Boletim Epidemiológico AIDS. Epidemiologia da Transmissão Vertical do HIV no Brasil. Brasília: Ministério da Saúde. Secretaria de Políticas de Saúde. Coordenação Nacional de DST/Aids; 1999;12(3):22-34.

Boletim Epidemiológico AIDS. Vigilância de HIV em Gestantes e Crianças Expostas. São Paulo: Secretaria de Estado. Programa Estadual de DST/AIDS; 2001;(1).

Boletim Epidemiológico AIDS do Município de São Paulo. São Paulo:

Secretaria Municipal da Saúde. Programa de DST/AIDS; 2003a;(7).

Boletim Epidemiológico AIDS. $1^{\text {a }}$ a $52^{\text {a }}$ Semanas Epidemiológicas. Brasília: Ministério da Saúde. Secretaria de Vigilância em Saúde. Programa Nacional de DST e Aids; 2003b;18(1).

Boletim Epidemiológico AIDS. Vigilância de Óbitos por AIDS. São Paulo: Secretaria de Estado da Saúde. Programa Estadual de DST/AIDS; 2004a;23(1). 
Boletim Epidemiológico AIDS. $1^{\text {a }}$ a $26^{\text {a }}$ Semanas Epidemiológicas. Brasília: Ministério da Saúde. Secretaria de Vigilância em Saúde. Programa Nacional de DST e Aids; 2004b;1(1).

Boletim Epidemiológico AIDS. Vigilância de HIV em Gestantes e Crianças Expostas. São Paulo: Secretaria de Estado da Saúde. Programa Estadual de DST/ AIDS; 2005;(1).

Brasil. Ministério da Saúde. Secretaria de Políticas de Saúde. Coordenação Nacional DST/AIDS. Guia de tratamento: recomendações para profilaxia da transmissão materno infantil do HIV e terapia anti-retroviral em gestantes.

Brasília; 2001a.

Brasil. Ministério da Saúde. Secretaria de Políticas de Saúde. Área Técnica de Saúde da Mulher. Parto, aborto e puerpério: assistência humanizada à mulher. Brasília: Ministério da Saúde; 2001b. p. 18.

Cabral CS. Maternidade e AIDS: desejo e representações. Cad Saúde Pública. 1997;5(2):171-85.

Couto MHC. Novos horizontes para as políticas públicas em HIVIAIDS: uma aproximação às questões de contemporaneidade [dissertação]. Rio de Janeiro: Universidade Estadual do Rio de Janeiro; 2002.

Cunha CC. Revelando e desvelando olhares: o significado do tratamento para o HIVIAIDS [dissertação]. Rio de Janeiro: Escola Nacional de Saúde Pública, Fundação Oswaldo Cruz; 2004.

Del Bianco R. Controle da transmissão vertical do HIV e Sífilis. In: Mesquita F, organizador. DST/AIDS: a nova cara da luta contra a epidemia na cidade de São Paulo. São Paulo: Secretaria Municipal da Saúde. Coordenação Municipal de DST/AIDS; 2003.

Dias EAC. Entre o desejo e o risco: os sentidos da gravidez na assistência à Aids. São Paulo [dissertação]. São Paulo (SP): PUC; 1999.

Falcke D, Wagner A. Mães e madrastas: mitos sociais e autoconceito. Estudos Psicol. 2000;5(2):421-41.

Guimarães CD. Aids no feminino: por que a cada dia mais mulheres contraem Aids no Brasil?. Rio de Janeiro: Ed. UFRJ, 2001.

Guimarães R, Ferraz AF. A interface Aids, estigma e identidade: algumas considerações. REME Rev Min Enferm. 2002;6(1/2):77-85.

Helman CG. Cultura, saúde e doença 2ª ed. Porto Alegre: Artes Médicas; 1994. 
Heilborn ML, Gouveia PF. "Marido é tudo igual": mulheres populares de sexualidade no contexto da AIDS In: Barbosa R, Parker R, organizadores. Sexualidades pelo avesso: direitos, identidades e poder. São Paulo: Ed. 34; 1999. p. $175-98$.

Knauth DR, Barbosa RM, Hopkins K, Pegorario M, Fachini R. Cultura médica e decisões reprodutivas entre mulheres infectadas pelo vírus da Aids. Interface Comun Saúde Educ. 2002;6(11):39-54.

Knauth DR. Subjetividade feminina e soropositividade In: Barbosa RM, Parker $\mathrm{R}$, organizadores. Sexualidade pelo avesso: direitos, identidades e poder. São Paulo: Ed. 34; 1999. p.122-36.

Landroni MAS. AIDS e gravidez: desafios para o cuidado nos Serviços de Saúde [dissertação]. São Paulo (SP): Faculdade de Saúde Pública da USP; 2004.

Levine C, Dubler NN. HIV and childbearing 1. Uncertain risks an bitter realities: the reproductive choices of HIV-infected women. Milbank Q. 1990;68(3):321-51.

Marins JR, Jamal LF, Chen SY, Barros MB, Hudes ES, Barbosa AA, et al. Dramatic improvement in survival among adult Brasilian Aids patients. Aids. 2003;17(11):1675-82.

Mann J, Tarantola DJM, Netter TW. A AIDS no mundo. Rio de Janeiro: RelumeDumará; 1993.

Mello Filho J. Sexualidade e Família In: Mello Filho J, Burd M, Organizadores. Doença e Família. São Paulo: Ed. Casa do Psicólogo; 2004. p. 57-74.

Minayo MCS. O desafio do conhecimento: pesquisa qualitativa em saúde. São Paulo: Hucitec; 2004. p. 105-96.

Moura EL. Transmissão vertical do HIV: percepção e ações da gestante soropositiva [dissertação]. São Paulo (SP): Faculdade de Saúde Pública da USP; 2004.

Neves LAS. Prevenção da transmissão vertical do HIV/Aids: compreendendo as crenças e percepções das mães soropositivas [dissertação]. Ribeirão Preto (SP): Escola de Enfermagem de Ribeirão Preto/USP; 2005.

Oliveira LA, França Junior I. Demandas reprodutivas e a assistência às pessoas vivendo com HIVIAIDS: limites e possibilidades no contexto dos serviços de saúde especializados. Cad Saúde Pública. 2003;19 Supl 2:315-23. 
Oliveira RN. As práticas de saúde para redução da transmissão vertical do HIV em Unidades de Atenção Básica: realidade e determinantes [dissertação]. São Paulo (SP): Faculdade de Saúde Pública da USP; 2004.

Paiva MS. Vivenciando a gravidez e experienciando a soropositividade para o HIV [tese]. São Paulo (SP): Escola de Enfermagem da USP; 2000.

Paiva V, Latorre MR, Gravato N, Lacerda R. Enahncing care initiative (ECBrasil). Sexualidade das mulheres portadoras de HIVIAids. Cad Saúde Pública. 2002;18(6):1609-20.

Parker R, Galvão J, organizadores. Quebrando o silêncio: mulheres e AIDS no Brasil. Rio de Janeiro: Relume Dumará; 1996.

Remien R. Uma revisão dos desafios para casais sorodiscordantes e questões de saúde pública implicações para intervenções. In: Parker R, Pimenta MC, Terto Junior V, Maksud I. Conjugalidade e Aids: a questão da sorodiscordancia e os serviços de saúde. Rio de Janeiro: ABIA; 2002. p. 21-5.

Rohden F. Comentários prevenção e reprodução no contexto HIVIAIDS. In: Parker R, Pimenta MC, Terto Junior V, Maksud I. Conjugalidade e Aids: a questão da sorodiscordancia e os serviços de saúde. Rio de Jnaiero: ABIA; 2002. p. 69-72.

Ruggiero EM. Gestante portadora do vírus HIV: vida e significado [tese]. Ribeirão Preto (SP): Escola de Enfermagem de Ribeirão Preto/USP; 2000.

Saldanha AAW, Figueiredo MAC. Gênero, Relações afetivas e aids no cotidiano da mulher soropositiva. In: $3^{\circ}$ HIV-AIDS Virtual Congress; [online] 2002. Disponível em:

http://www.aidscongress.net/article.php?id comunicacao=99 [Acesso 2 ago . 2006].

Sande MA, Elioupolos GM, Moellering Junior R, Gilbert DN. Guia Sanford para tratamento de HIVIAIDS 2005. São Paulo: Ed. Médica A.W.W.E.; 2005. p. 30, 132.

Santos NJS, Buchalla CM, Fillipe EV, Bugamelli L, Garcia S, Paiva V. Mulheres HIV positivas, reprodução e sexualidade. Rev Saúde Pública. 2002;36(4):12-23.

São Paulo (Cidade). Secretaria Municipal da Saúde. Área Temática DST/AIDS. A AIDS na cidade de São Paulo [online]. São Paulo; 2004a. Disponível em: http://www10.prefeitura.sp.gov.br/dstaids/novo site.aids/index.php?texto=aidss p. [Acesso 26 jul . 2005]. 
Sherlock MSM, Vieira NF. Preocupações de mães soropositivas com o HIV e suas implicações para o cuidado de enfermagem. J Bras DST. 1999;11(4)5-9.

Shimma E. Vinte anos de luta contra a aids GIV notícias [online]. Disponível em : http:// www.hotlink.com.br/cgi-bin/busca.cgi [Acesso 28 nov. 2003].

Silva NEK, Oliveira LA, Fiqueiredo WS dos, Landroni MAS, Waldman CCS, Ayres JRCM. Limites do trabalho multiprofissional: estudo de caso dos centrosde referência para DST/Aids. Rev. Saúde Pública 2002; 36 (4 Supl):108-116

Silva NEK. AIDS e gravidez: os sentidos do risco e o desafio do cuidado. [dissertação]. São Paulo (SP): Faculdade de Saúde Pública da USP; 2003.

Souza Junior PRB, Szwarcwald CL, Barbosa Junior A. Infecção pelo Hiv durante a gestação: estudo-sentinela parturiente, Brasil, 2002. Rev Saúde Pública. 2004;38(6):764-72.

Teixeira PR, Paiva V, Shimma E. Ta difícil de engolir? Experiências de adesão ao tratamento anti-retroviral em São Paulo. São Paulo: NEPAIDS; 2000. p. 1.

Villela WV. Vulnerabilidade, sexualidade e subjetividade: sobre a face feminina da aids. In: Carvalho MEG, Carvalhaes FF, Cordeiro RP, organizadoras.

Cultura e subjetividade em tempos de AIDS. Londrina: Associação Londrinense Interdisciplinar de AIDS; 2005. p.65-77

Zihlmann KF. A questão do desejo da gravidez e da maternidade em mulheres vivendo com HIV/Aids na perspectiva psicanalítica [dissertação]. São Paulo (SP): Faculdade de Saúde Pública da USP; 2005. 
ANEXOS 


\section{Anexo 1}

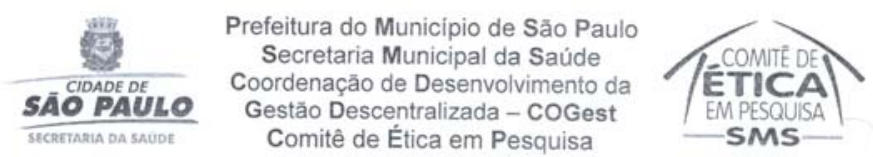

São Paulo, 09 de Agosto de 2005.

PARECER N ${ }^{\circ} 083 / 2005-$ CEP/SMS

Prezado (a) Senhor (a)

Pelo presente, informo que o Comitê de Ética em Pesquisa da Secretária Municipal de Saúde de São Paulo analisou, e APROVOU, de acordo com a Resolução CNS 196/96, o protocolo de pesquisa "As implicaçōes de ser māe no controle do processo saúde - doença em mulheres com AIDS-CAAE 0052/05, de autoria do(a) pesquisador(a) Marli Aparecida Silva Athaniel.

Como procedimento adotado por este Comité de Ética em Pesquisa, solicitamos a inclusão, no Termo de Consentimento Livre e Esclarecido do seguinte: qualquer questâo, dúvida, esclarecimento ou reclamaçăo sobre os aspectos éticos dessa pesquisa, favor entrar em contato com: Comité de Ética em Pesquisas da Secretana Municipal da Saude de Sáo Paulo - Rua General Jardim, $36-2^{n}$ andar Telefone: 3218-4043 - e-mail: smscep@prefeitura.sp.gov.br

Lembramos que este parecer não basta para que seu estudo possa se realizar dentro da unidade, é necessária também a permissão administrativa da autoridade sanitária.

Salientamos os seguintes aspectos a serem considerados pelo pesquisador:

- O sujeito da pesquisa tem a liberdade de recusar-se a participar ou de retirar seu consentimento em qualquer fase da pesquisa, sem penalizaçāo alguma ou sem prejuizo ao seu cuidado (Res. CNS 196/96 - item IV.1f) e deve receber uma cópia do Termo de Consentimento livre e esclarecido, na integra, por ele assinado (item IV.2.d)

- O pesquisador deve desenvolver a pesquisa conforme delineada no protocolo aprovado. Eventuais modificaçōes ou emendas ao protocolo devem ser apresentadas ao CEP de forma clara e sucinta, identificando a parte do protocolo a ser modificada suas justificativas. O relatório final deve ser apresentado ao CEP, logo que o estudo estiver concluido.

$$
\text { Atenciosamente, }
$$

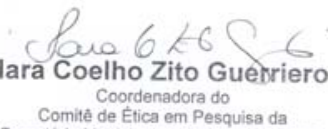

Secretaria Municipal da Saúde - CEPSMS

IImo(a). Sr(a)

Marli Aparecida Silva Athaniel

Universidade de São Paulo

Nesta

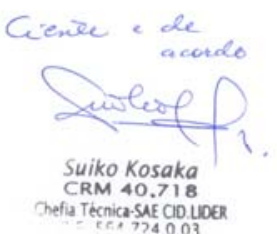

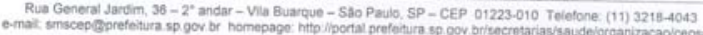




\section{Anexo 2}

\section{TERMO DE CONSENTIMENTO LIVRE E ESCLARECIDO}

Meu nome é Marli Aparecida Silva Athaniel, sou enfermeira e, como aluna do Curso de Mestrado do Programa de Pós-Graduação em Enfermagem da Universidade de São Paulo, estou realizando um estudo denominado "Os significados e implicações de ser mãe no controle do processo saúde-doença em mulheres com aids", sob a orientação da Profa. Dra. Renata Ferreira Takahashi.

O estudo tem a finalidade de fornecer subsídios para melhorar a qualidade da assistência às mulheres soropositivas ao HIVIAIDS e os objetivos de caracterizar as condições de vida e trabalho de mães com HIVIAIDS, identificar os significados atribuídos à maternidade por mães com HIVIAIDS e identificar as repercussões de ser mãe no controle do processo saúde-doença de mulheres com HIVIAIDS.

Gostaria de convidá-la a participar da minha pesquisa. Para o desenvolvimento do estudo, necessito entrevistá-las e fazer algumas perguntas, as quais você poderá ler e caso tenha dúvidas, eu posso esclarecê-las antes de iniciar a entrevista. Para que eu não perca nenhuma informação importante, necessito que a entrevista seja gravada.

A sua participação é voluntária, você tem a liberdade para desistir a qualquer momento durante o processo de coleta de dados se desejar, sem prejuízo algum em relação ao atendimento aqui no serviço.

Seu nome não aparecerá no trabalho e será guardado sigilo de dados confidenciais.

Caso sinta necessidade de entrar em contato comigo durante e/ou após a coleta de dados, poderá fazê-lo pelo telefone.

A entrevista será gravada e você poderá ouvi-la, se assim desejar.

Ao final da pesquisa, se for de seu interesse, você poderá ver os resultados e conversar comigo a respeito.

Sua participação será muito importante.

São Paulo, de de 2005 


\section{Anexo 3}

Ficha de Caracterização sócio-demográfica e condições de vida e trabalho

1. $N^{\circ}$ da entrevista : $\quad N^{\circ}$ do prontuário:

2. Data:

Dados sócio-demográficos:

3. Nome (iniciais)

4. Endereço:

5. Escolaridade da mãe (em anos de estudo):
Analfabeta ( )
De 1 a 3 anos ( )
De 8 a 11 anos ( )
De 12 anos e + ( )
De 4 a 7 anos ( )
Ignorada ( )

6. Sexo: masc. ( ) fem. ( )

7. Raça: branca ( ) preta ( ) amarela ( ) parda ( ) outra ( )

8. Estado marital: solteira ( ) casada ( ) viúva ( ) outra ( )

9. Vive com: sozinha ( ) casada ( ) viúva ( ) outra ( )

Dados sobre o processo saúde-doença (filhos, mãe e marido/companheiro)

10. Filhos:

\begin{tabular}{|l|l|l|l|l|}
\hline $\begin{array}{l}\text { Pré-sorop. ao } \\
\text { HIV }\end{array}$ & $\begin{array}{l}\text { Pós-sorop. ao } \\
\text { HIV }\end{array}$ & $\begin{array}{l}\text { Idade } \\
\text { atual }\end{array}$ & $\begin{array}{l}\text { Situação } \\
\text { atual (vivo, } \\
\text { morto) }\end{array}$ & $\begin{array}{l}\text { HIV+ } \\
\text { HIV- }\end{array}$ \\
\hline & & & & \\
\hline & & & & \\
\hline & & & & \\
\hline & & & & \\
\hline & & & & \\
\hline & & & & \\
\hline
\end{tabular}

11. Tempo de diagnóstico da soropositividade da mãe (anos, meses): 
12. Local do diagnóstico (serviço):

13. Tempo de matrícula no SAE (anos, meses):

14. Realização do pré-natal: $n^{\circ}$ de consultas:

15. Situação do marido/companheiro: HIV+/ AIDS ( ), tempo: HIV- ( )

16. Ações de prevenção de transmissão da TV realizadas durante o pré-natal: . orientação sobre a transmissão e risco da gravidez ( ) . aconselhamento sobre o planejamento da gravidez ( ) . ingestão da TARV ( )

. fornecimento do Kit maternidade ( )

. encaminhamento para a maternidade ( )

. orientação na maternidade sobre a suspensão da amamentação ( )

. fornecimento de leite artificial ( )

. fornecimento de medicação para o RN ( )

. outras ( )

17. Adesão ao controle do seu processo saúde-doença no SAE antes de se tornar mãe:
. à realização de exames: sim ( )
não ( )
. às consultas médicas agendadas: sim( ) não ( ),faltosa por..meses
. participação em outras atividades realizadas no SAE: sim ( ) não ( )

\section{Condições de vida e trabalho:}

18. Profissão:

19. Ocupação atual:

20. Situação empregatícia atual:

\begin{tabular}{|c|c|c|c|c|c|c|}
\hline $\begin{array}{l}\text { Pessoas que } \\
\text { integram a } \\
\text { família }\end{array}$ & $\begin{array}{l}\text { Com vínculo } \\
\text { empregatício }\end{array}$ & $\begin{array}{l}\text { Sem vínculo } \\
\text { empregatício }\end{array}$ & $\begin{array}{l}\text { Apo- } \\
\text { sen- } \\
\text { tado }\end{array}$ & $\begin{array}{l}\text { Recebe } \\
\text { apoio } \\
\text { financeiro }\end{array}$ & $\begin{array}{l}\text { Renda } \\
\text { familiar }\end{array}$ & $\begin{array}{l}N^{\circ} \text { de } \\
\text { pessoas } \\
\text { dependente } \\
\text { da renda } \\
\text { familiar }\end{array}$ \\
\hline \multicolumn{7}{|l|}{ Mãe } \\
\hline \multicolumn{7}{|l|}{$\begin{array}{l}\text { Marido/ } \\
\text { companheiro }\end{array}$} \\
\hline & & & & & & \\
\hline & & & & & & \\
\hline & & & & & & \\
\hline & & & & & & \\
\hline
\end{tabular}


21. O local em que você mora é: casa ( ) apartamento ( ) barraco ( ) cortiço ( ) outro ( )

22. Possui: rede pública de abastecimento de água ( ) outro ( )

23. Possui: rede pública de esgoto ( ) despejado em rio, córrego ( ) fossa ( )

24. A coleta de lixo é: pelo serviço público ( ) 1 a 2 vezes por semana ( )

25. A casa em que mora é: ( ) própria invadida ( ) outro ( )

26. Quantos cômodos existem (distribuição ao dormir):

27. A família possui:

\begin{tabular}{|l|l|l|}
\hline & Sim & Não \\
\hline Outra propriedade & & \\
\hline Carro & & \\
\hline Computador & & \\
\hline Microondas & & \\
\hline Som com CD & & \\
\hline
\end{tabular}

28. Qual atividade realiza como lazer?

\begin{tabular}{|l|l|}
\hline Esporte & Qual? \\
\hline Leitura & \\
\hline TV/Vídeo & \\
\hline Cinema & \\
\hline Teatro & \\
\hline Outra atividade & Qual? \\
\hline
\end{tabular}


Questões orientadoras:

1. Fale um pouco sobre a rotina do seu dia a dia antes de você ser mãe

2. Fale um pouco sobre a rotina atual do seu dia a dia, o cuidado com sua saúde, com a saúde do seu filho(a) ... 